\title{
Braterstwo Dawida i Jonatana. Obraz męskiej przyjaźni w 1 Sm 18 - 2 Sm 1
}

The Brotherhood of David and Jonathan. The Picture of Male Friendship in 1 Sam 18 - 2 Sam 1

\section{DARIUSZ DZIADOSZ}

Katolicki Uniwersytet Lubelski Jana Pawła II

dariuszdzi@op.pl, ORCID: 0000-0002-5191-0560

\begin{abstract}
Streszczenie: W wielu biblijnych publikacjach naukowych i popularyzatorskich na przestrzeni ostatnich dekad toczy się żywa debata na temat charakteru relacji łączącej Dawida i Jonatana, utrwalonej w Księgach Samuela. Niektórzy przypisują tej więzi podtekst homoseksualny, a przynajmniej homoerotyczny, jednakże tego typu interpretacja nie znajduje potwierdzenia w materiale źródłowym $1 \mathrm{Sm} 18$ - 2 Sm 1 . Cykl o dojściu Dawida do władzy (1 Sm 16,1 - 2 Sm 5,5) nie komunikuje wyraźnych sygnałów, które wskazują na seksualne podłoże relacji międzyosobowej pretendentów do tronu. Sugerowana przez niektórych autorów lektura tradycji 1 Sm 18,1 - 2 Sm 1 w kluczu idei homoseksualizmu oraz jej więź z Pieśnią nad Pieśniami dotyczy jedynie płaszczyzny terminologicznej i nie pozwala przypisać tekstom z Pierwszej Księgi Samuela wydźwięku intymnego (homoerotycznego). Opisując braterską więź Jonatana i Dawida, deuteronomista akcentuje nade wszystko jej teologiczny i społeczno-polityczny aspekt, co nie oznacza, że utrwalony przez niego obraz męskiej przyjaźni nie posiada mocnego zabarwienia emocjonalno-uczuciowego.
\end{abstract}

Słowa kluczowe: relacja Dawida i Jonatana, braterstwo, homoseksualny (homoerotyczny) podtekst w $1 \mathrm{Sm} 18,1-21,1$

\begin{abstract}
Over the last decades many scientific and popularizing biblical publications have debated the nature of David and Jonathan's relationship described in 1 and 2 Samuel. Several exegetes have interpreted this relationship as homosexual or at least homoerotic, but such an interpretation does not correspond to the text of 1 Sam 18 - 2 Sam 1. The narrative of David's ascent to the throne (1 Sam 16, 1 - 2 Sam 5, 5) does not provide direct indications of a sexual background to the interpersonal relationship between the two claimants to the throne. The connections between 1 Sam 18 - 2 Sam 1 and Song of Songs concern only the terminology and do not allow one to ascribe sexual (homoerotic) connotations in the stories of 1 Samuel. The Deuteronomist emphasizes a primarily theological and socio-political level of the brotherhood between David and Jonathan, but his idea of the male friendship in 1 Sam 16, 1 - 2 Sam 5, 5 also has a strong emotional aspect.
\end{abstract}

Keywords: David and Jonathan relationship, brotherhood, homosexual (homoerotic) overtones in 1 Sam 18,1-21,1

W ostatnich latach pojawiło się wiele naukowych i popularyzatorskich publikacji, które badają biblijną koncepcję ludzkiej seksualności oraz biblijną ocenę relacji homoseksualnych. Wśród tego typu analiz coraz częściej spotyka się takie, które źródłowe teksty Biblii traktują instrumentalnie. Interpretując je w sposób tendencyjny 
i pragmatyczny, nierzadko prowadzą do nieuzasadnionej deformacji ich oryginalnego orędzia ${ }^{1}$. Współcześni komentatorzy usiłujący złagodzić stanowcze stanowisko autorów natchnionych w kwestii więzi homoseksualnych, ale też zbyt zagorzali reprezentanci środowisk przeciwnych ideologii i kulturze homoseksualnej, często naginają do własnych współczesnych przekonań i celów teksty Biblii, zapominając lub świadomie pomijając fakt, iż te źródła odzwierciedlają realia religijno-kulturowe i społeczne sprzed kilku tysięcy lat ${ }^{2}$, które pod wieloma względami nie przystają do obecnych standardów ${ }^{3}$. Obie strony tej ideowo-religijnej debaty nie uwzględniają tego, że Biblia Hebrajska, Biblia chrześcijańska oraz pisma Ojców Kościoła ${ }^{4}$ nie znają pojęcia „homoseksualizm”, a w związku z tym nie definiują tego zjawiska ${ }^{5}$. Teksty staro- i nowotestamentowe mówią wprost tylko o postawach i czynach homoseksualnych, odnosząc je prawie wyłącznie do mężczyzn ${ }^{6}$ i za każdym razem stanowczo je potępiając ${ }^{7}$. A zatem te komentarze egzegetyczno-teologiczne, które bezkrytycznie przenoszą dzisiejsze realia kulturowo-religijne oraz normy prawne na świat Biblii i odwrotnie, tracą wiarygodność. Przykładem takiej nieuprawnionej i nieuzasadnionej współczesnej lektury Biblii jest interpretacja historii Jonatana i Dawida

1 Balch, Homosexuality; Brawley, Biblical Ethics; Comstock, Gay Theology; Gerig, „Jonathan and David: Their Three Covenants”; Gerig, „Jonathan and David: The Debate Continues”; Harding, The Love of David and Jonathan; Heacock, Jonathan Loved David; Horner, Jonathan Loved David, 26-39; Krondorfer, „Who's Afraid of Gay Theology?”, 257-274. Ukazują się też monografie, które tę problematykę analizują za pomocą metodologii właściwej dla egzegezy biblijnej: Davidson, Flame of Yahweh; Himbaza - Schenker Edart, The Bible; De Young, Homosexuality.

2 Najstarsze ustne, a następnie pisane wersje analizowanych niżej tradycji o Saulu, Dawidzie i Jonatanie należy wiązać z przełomem drugiego i pierwszego tysiąclecia przed Chr. Ich aktualna forma nosi na sobie jednak ślady wielowiekowego procesu redakcji, który trwał do epoki perskiej. Nihan - Nocquet, „1-2 Samuel", 286-288.

3 Ackerman, When Heroes Love, 165-199; Römer, „Homosexualität in der Hebräischen Bibel?”, 436.

4 Petersen, „On the Study of “Homosexuality” in Patristic Sources”, 113-114.

$5 \mathrm{Ci}$, którzy z góry zakładają, że autorzy biblijni znali i oceniali homoseksualizm w sposób porównywalny do współczesnego, i czytają Biblię, by znaleźć w niej za wszelką cenę promocję, a przynajmniej tolerancję dla orientacji i postaw homoseksualnych, albo też ich szeroko uzasadnione potępienie, nie są egzegetami badającymi źródła natchnione. Stają się raczej samozwańczymi interpretatorami Biblii, którzy narzucają jej współczesny kod kulturowy i moralno-etyczny. Dla autorów biblijnych i starożytnego Bliskiego Wschodu każda manifestacja seksualności człowieka - czyli pragnienia, odczucia, emocje i płynące z nich czyny - była integralnym elementem jego złożonej tożsamości, którą należało rozumieć i oceniać w szerokim pryzmacie jej pozostałych cech, aspektów i płaszczyzn oddziaływania. Wyróżnianie osób z uwagi na ich odmienną orientację seksualną czy uzależnianie od niej ich pozycji i roli społecznej jest tworem współczesnym i było czymś obcym dla kultury i religii Biblii oraz starożytnych cywilizacji bliskowschodnich. Zob. Tamagne, „Naissance du troisième sexe”, 48-55; Countryman, „Homosexuality”, 602; Furnish, „Homoseksualizm”, 398-399.

6 Jedynym biblijnym świadectwem sugerującym homoseksualizm kobiet jest List do Rzymian (1,26).

7 Biblia porusza temat relacji homoseksualnych tylko w kontekście oceny moralno-jurydycznej, oferując w tym zakresie trzy rodzaje tradycji: teksty opisujące czyny (postawy) homoseksualne konkretnych ludzi i grup społecznych (Rdz 19,1-29; Sdz 19,1-30), normy i regulacje prawne definiujące ich stosunek do przykazań Bożych (Kpł 18,22; 20,13) oraz passusy o podłożu doktrynalno-moralnym (Rz 1,26-27; 1 Kor 6,9; 1 Tm 1,10). 
(1 Sm 18 - 2 Sm 1) w kluczu relacji homoseksualnej, która będzie przedmiotem niniejszej publikacji.

\section{Cel badawczy i metodologia analizy materiału źródłowego}

Zadaniem artykułu jest precyzyjna definicja natury relacji Dawida $\mathrm{z}$ Jonatanem opisanej w tzw. cyklu o dojściu Dawida do władzy (1 Sm 16,1 - 2 Sm 5,5), w której wielu współczesnych autorów na bazie nieuprawnionej lektury obecnych w nim pojęć i formuł widzi podtekst homoseksualny (homoerotyczny) ${ }^{8}$. Celem badań będzie więc dokładny opis pola semantycznego tych hebrajskich terminów i zdefiniowanie rzeczywistego orędzia płynącego z poszczególnych źródeł Pierwszej i Drugiej Księgi Samuela i ich kolejnych redakcji w kwestii więzi łączącej obu młodzieńców. Już na samym wstępie trzeba zaznaczyć, że na podstawie dostępnych tekstów źródłowych i obowiązujących w egzegezie biblijnej kryteriów oceny będzie można udzielić odpowiedzi jedynie na pytanie o to, czy opisane w Biblii zewnętrzne manifestacje męskiej relacji Dawida i Jonatana (czyny, słowa i postawy wyrażające wewnętrzny stan ducha) były przez autorów uważane za homoseksualne. Oczywiście ta odpowiedź będzie bazować na starożytnej, a nie aktualnej idei homoseksualizmu i jego ówczesnej kulturowo-moralnej ocenie. Z uwagi na brak źródeł i odpowiednich narzędzi badawczych, niemożliwe będą natomiast wnioski w zakresie ewentualnych homoseksualnych skłonności, pragnień i odczuć biblijnych bohaterów. W tej materii Księgi Samuelowe się po prostu nie wypowiadają, stąd jakiekolwiek komentarze na ten temat mają z konieczności wartość tylko teoretycznych dywagacji naznaczonych znamionami współczesnej idei homoseksualizmu.

1 Sm 16,1 - 2 Sm 5,5 to złożony pod względem literackim, redakcyjnym i tematycznym zbiór tradycji, których ustna forma przekazu sięga opisywanych zdarzeń (przełom XI i X w. przed Chr.), a pierwotna forma pisana, w przypadku przynajmniej niektórych źródeł, mogła powstać już w epoce Salomona, a z pewnością stopniowo krystalizowała się w okresie rządów późniejszych przedstawicieli dynastii Dawidowej (VIII-VII w. przed Chr.) ${ }^{9}$. Aktualna wersja tych tradycji jest jednak owocem złożonego procesu redakcji, który trwał aż do okresu perskiego, kiedy to dokonała się ostateczna edycja Ksiąg Samuela i ich włączenie w deuteronomistyczne dzieje Izraela $(\mathrm{Joz}-2 \mathrm{Krl})^{10}$. Pilną potrzebę rzetelnej analizy centralnej sekcji tego zbioru (1 Sm 18,1 - 2 Sm 1,27) pod kątem literackiego profilu jej najważniejszych bohaterów: Saula, Jonatana i Dawida, dyktuje rosnące w ostatnich latach zainteresowa-

\footnotetext{
Schroer - Staubli, „Saul, David, and Jonathan”, 35-36.

Dietrich, „Stefan Heyms Ethan ben Hoshaja”, 21-22.

Zob. Dietrich, „Doch ein Text hinter den Texten?”, 133-159.
} 
nie tą częścią Ksiąg Samuela, a nade wszystko jej rozbieżne i często nieuzasadnione merytorycznie interpretacje. Porządkując funkcjonujące obecnie w kręgach naukowych i popularyzatorskich publikacje na temat źródeł o Dawidzie i Jonatanie, można wskazać na trzy zasadnicze linie interpretacyjne: 1) tradycyjna, która o więzi dwu młodzieńców mówi w kluczu męskiej przyjaźni i braterstwa, osadzając ją głęboko w społeczno-politycznych i militarnych realiach wojny Izraela z Filisteą i wewnętrznej walki o tron w Izraelu między rodami Beniamina i Judy; 2) kompromisu, która w źródłach biblijnych nie dostrzega oczywistych przesłanek pozwalających na ocenę relacji tych dwu bohaterów w kategorii homoseksualnej, jednakże na bazie obecnej w nich ambiwalentnej terminologii oraz miejscami dość sugestywnej metaforyki i symboliki, pozwala lektorom Biblii dostrzec w więzi Dawida i Jonatana podtekst intymny, wykraczający poza ramy ogólnie przyjętej konwencji aseksualnej relacji politycznej lojalności, wierności i braterstwa broni; 3) lekturę Biblii promująca idee i postawy homoseksualne (A Queer Reading of the Bible), która większą wagę przykłada do sytuacji egzystencjalnej lektora, w tym wypadku sytuacji kogoś, kto utożsamia się z kręgami homoseksualnymi i propagowaną przez nie ideologią, aniżeli do oryginalnego orędzia Bibliii ${ }^{11}$. Ta grupa komentatorów, która ostatnio coraz mocniej rości sobie prawo do statusu oficjalnej szkoły egzegezy biblijnej, określa relację Jonatana i Dawida wprost jako homoseksualną ${ }^{12}$.

Formułowane niżej wnioski będą wypływać $\mathrm{z}$ analizy historyczno-krytycznej biblijnego tekstu, która wciąż pozostaje główną metodą badawczą pism historycznych Biblii Hebrajskiej. Do ukazania szerszego kontekstu badanego problemu posłuży też metoda analizy narracyjnej i intertekstualnej lektury Biblii, które pozwolą na rzetelne zbadanie kontekstu historycznego i teologicznego opisywanych zdarzeń i postaci. W ocenie Jonatana i Dawida oraz ich wzajemnej relacji trzeba zwrócić uwagę nie tylko na sposób, w jaki ukazali ich autorzy kolejnych źródeł Pierwszej i Drugiej Księgi Samuela i ich redaktorzy, ale także na ówczesne realia historyczne (społeczno-kulturowe i religijno-prawne) w Izraelu. Aby zdobyć wiarygodne informacje w tym zakresie, należy zaprezentować historię Dawida i Jonatana w świetle innych biblijnych tekstów (narracyjnych i prawnych) mówiących o związkach przedstawicieli jednej płci. Na każdym etapie analiz trzeba nadto zachować duży dystans do współczesnej społeczno-kulturowej i etyczno-moralnej oceny homoseksualizmu. Gdyby bowiem nawet więź Dawida z Jonatanem nosiła znamiona głębokiej relacji emocjonalnej i uczuciowej, nie oznacza to wcale, że biblijny autor myślał o tym samym, co współcześni, gdy słyszą o intymnej więzi między mężczyznami ${ }^{13}$. Pojęcia: homoseksualizm,

11 Goss - West, Take Back the Word; Stone (red.), Queer Commentary.

12 Jobling, 1 Samuel, 161-165; Heacock, Jonathan Loved David, 130-150.

13 Współczesne kategorie i pojęcia definiujące homoseksualizm, homoerotyzm czy homosocjalność, prócz odmienności leksykalnej (literackiej), komunikują daleko inny sens aniżeli terminy biblijne. To sprawia, że mogą one być odniesione do prezentacji i oceny postaw, intencji i zachowań bohaterów Biblii Hebrajskiej jedynie na zasadzie analogii. Kontekst społeczno-kulturowy oraz system etyczno-moralny starożytnego 
homoerotyzm czy homosocjalność ${ }^{14}$, których używa się dziś w dość ambiwalentnym i szerokim sensie ${ }^{15}$, tylko w pewnej i ograniczonej mierze odzwierciedlają rzeczywistość opisaną w Biblii.

\section{Specyfika narracyjna i historyczno-kulturowa $1 \mathrm{Sm} \mathrm{18,1} \mathrm{-} 2 \mathrm{Sm} \mathrm{1,27}$}

Kolejne odsłony opowieści o braterstwie Jonatana z Dawidem (1 Sm 18 - 2 Sm 1) zostały wpisane w dominujący w Księgach Samuela nurt tematyczny, który relacjonuje społeczno-polityczne i militarne realia ustanowienia i utrwalenia monarchii w Izraelu. W opinii narratora wątek tej młodzieńczej przyjaźni ma wymiar epizo-

Bliskiego Wschodu i Izraela w kwestii odczuć, emocji i relacji międzyludzkich jest w dużej mierze niezrozumiały i bardzo odległy dla współczesnych. Taki rodzaj intymności, jak np. pocałunek czy objęcie, w jednej kulturze czy epoce jest zwykłym przejawem przyjaźni, bliskości i szacunku, w innej ma już podtekst erotyczny (seksualny), choć jest do przyjęcia w stosunku do pewnej grupy osób złączonych więzami pokrewieństwa czy zażyłości, natomiast jeszcze w innej nosi znamiona gestu erotycznego (seksualnego), którego nie można zaakceptować z uwagi na przyjęte normy i zwyczaje. Stąd te sceny biblijne, które współczesnym lektorom wydają się manifestacją uczuć i więzi typowych dla współczesnej konwencji relacji czy postaw homoseksualnych, niekoniecznie musiały mieć taki status w epoce, z której pochodzi lub której dotyczy konkretny tekst Biblii. Ogólny kanoniczny profil tradycji biblijnych sugeruje, że ich autorzy, zawsze gdy chcieli zasugerować intymne (seksualne, erotyczne) tło słów i czynów opisywanych bohaterów, czynili to w sposób niezawoalowany i pozbawiony dwuznaczności. Z tą samą siłą i bezpośredniością definiowali też wagę seksualnych nadużyć, choć nie podawali kryteriów proponowanej oceny, które pozwalałyby np. na ich klasyfikację. O tym, że koncepcja relacji homoseksualnych w starożytności biblijnej w zasadzie odpowiadała tej obecnej, można wnioskować jedynie na bazie ogólnego profilu tekstów biblijnych. Tylko w sferze oceny moralnej homoseksualizmu Biblia nie zostawia żadnych niedopowiedzeń, tak w tekstach prawnych (Kpł 18,22; 20,13), jak i narracyjnych (Rdz 19,1-11; Sdz 19,11-30; 1 Sm 18,1-3; 20,17; 2 Sm 1,26). Olyan, „And with a Male You Shall Not Lie”, 198; Wold, Out of Order, 107-114, 118-120. Tego faktu nie chcą jednak przyjąć współcześni autorzy promujący zazwyczaj romantyczną i wyidealizowaną wizję homoseksualizmu. Zob. Ackerman, When Heroes Love, 9-10, 165-167; Schroer - Staubli, „Saul, David, and Jonathan”, 24-26. Biblia Hebrajska, tak jak teksty starożytnego Bliskiego Wschodu, mówiąc o homoseksualnych więziach, ma na myśli nade wszystko konkretne czyny płynące z takich związków i wynikające z nich konsekwencje moralno-prawne i społeczne. Nie analizuje natomiast ich podłoża uczuciowo-emocjonalnego czy mentalnego. Zehnder, „Observations on the Relationship”, 132; Gagnon, The Bible and Homosexual Practice, 48, 146-154. Podobnie zresztą czynią autorzy źródeł z antycznej Grecji i Rzymu, pojmując homoseksualizm jako zewnętrzną postawę (czyn ludzki) o podtekście wyraźnie seksualnym i erotycznym, która dotyczy mężczyzn pochodzących z różnych przedziałów wiekowych i klas społecznych. Smith, „Ancient Bisexuality”, 236-237.

14 Anglojęzyczny termin „homosociability”, wypracowany na gruncie psychologii i socjologii, określa więź i różnoraką aktywność towarzyską przedstawicieli jednej płci (szczególnie mężczyzn), która nie posiada podłoża romantyczno-erotycznego i seksualnego. Zob. Hammaren - Johansson, „Homosociality”, 1-11; Slawik - Slawik, „Homoseksualizm problemem Kościoła?”, 11-13; Hügel, Homoerotik und Hebräische Bibel, 35-40.

15 Nissinen, Homoeroticism in the Biblical World, 16-17, 55-56; Haag - Ellinger, „Stört nicht die Liebe”, 145; Weizer, Vom anderen Ufer, 106-108; Nissinen, „Die Liebe von David und Jonatan”, 253-255, 261-262. 
dyczny, który poszerza spectrum historiozbawczej rekonstrukcji ostatnich dziesięcioleci XI w. przed Chr. Ukazane w kolejnych cyklach księgi (1 Sm 7,2-12,25; 13,1-15,35; 16,1 - 2 Sm 5,5) postacie Samuela, Saula, Jonatana i Dawida wpisano w historyczne ramy wojny Izraela z Filistynami i wewnętrznego konfliktu wynikłego $\mathrm{z}$ walki o władzę, jaka rozgorzała między rodem Beniamina a Judy i ich koalicjantami. Jeśli więc chce się odtworzyć wiarygodny i źródłowy obraz więzi Jonatana i Dawida, która wciąż budzi żywy oddźwięk i przybiera nowe formy wyrazu w religijnej i świeckiej literaturze i sztuce, trzeba koniecznie ukazać ją w wyżej sprecyzowanej perspektywie. Redaktorzy Ksiąg Samuela od początku bowiem akcentują jej tło polityczne (monarchiczne) i militarne, używając przy tym form i narzędzi typowych dla starożytnej bliskowschodniej historiografii, w tym też idei i terminów związanych ze sferą męskiej zażyłości i braterstwa. Ich sens jest jednak często dość odległy od analogicznych współczesnych pojęć, co w przypadku pominięcia lub celowej deformacji oryginalnego społeczno-kulturowego i ideowo-teologicznego kontekstu biblijnych tradycji, prowadzi najczęściej do nieadekwatnych i nieuprawnionych interpretacji i hipotez.

Biblijna rekonstrukcja więzi Jonatana i Dawida nie sugeruje wprost jej intymnego tła, w sensie relacji homoseksualnej (homoerotycznej). Takie wnioski mogą nasunąć się wtedy, gdy terminy i idee 1 Sm 18,1 - 2 Sm 1,27 zostaną wyrwane z oryginalnych literackich i historycznych ram Ksiąg Samuela. Bo choć w innych tekstach Biblii takie hebrajskie rdzenie, jak: ' $h b$, hpṣ, nšq czy $n^{\prime} m$ sugerują emocjonalno-uczuciowe i intymne zabarwienie relacji międzyludzkich, nie oznacza to jednak, że należy je przypisać a priori więzi, jaka łączyła pretendentów do tronu, co bezpodstawnie czynią niektórzy komentatorzy. W 1 Sm 16,1 - 2 Sm 5,5 terminy te przybierają nade wszystko wydźwięk ideowo-teologiczny i społeczno-kulturowy. W tym kluczu narrator na wiele sposobów, także za pomocą specjalnie dobranej terminologii, akcentuje siłę i wartość analizowanego braterstwa, by ukazać wagę jego politycznych i historiozbawczych następstw. Gdyby chciał skupić uwagę lektora na intymnym aspekcie więzi młodzieńców, użyłby środków wyrazu odpowiednich dla Biblii, np. rdzeni, które wprost odnoszą się do relacji miłosnych i seksualnych: škb „położyć się, współżyć, kochać się" (Kpł 18,22; 20,13), czy też jd "poznać, zbliżyć się seksualnie" (Rdz 19,5; Sdz 19,22). Brak tego typu pojęć w kompleksie tradycji 1 Sm 18,1-2 Sm 1,27 jest mocnym dowodem na to, że ani autorom oryginalnych źródeł w tym cyklu, ani ich późniejszym redaktorom nie chodziło o seksualny koloryt więzi Jonatana i Dawida ${ }^{16}$.

Braterstwo Jonatana z Dawidem jest pobocznym wątkiem bloku tradycji 1 Sm 16,1 - 2 Sm 5,5. Jego główną osnową narracyjną jest rekonstrukcja procesu

16 Na potwierdzenie można przytoczyć tu sposób prezentacji intymnej i seksualnej aktywności Dawida (2 Sm 11,1-12,25), Amnona (2 Sm 13,1-22) czy Absaloma (2 Sm 16,21-22) w analogicznych blokach tradycji. McKenzie, King David, 84-85. 
upadku Saula i wyniesienia na tron syna Jessego, do czego doprowadziła wojna Izraela $z$ Filistynami i konflikty w obrębie hebrajskich rodów. Kluczową reminiscencją tych ostatnich były społeczno-polityczne aspiracje rodu Judy, które na drodze militarnego przewrotu zrealizował Dawid (2 Sm 2,1-5,5). W tym właśnie pryzmacie biblijne teksty ukazują jego przyjaźń i przymierze z Jonatanem - oficjalnym pretendentem do tronu $\mathrm{z}$ ramienia pokolenia Beniamina. Celem autorów i redaktorów tych źródeł była ideowo-teologiczna prezentacja drogi Dawida do władzy. Pozostałe wątki zostały temu celowi podporządkowane, w tym opis i ocena osobistych i oficjalnych relacji, jakie Dawid utrzymywał kolejno z drugoplanowymi bohaterami cyklu ${ }^{17}$. W tę linię narracyjną zostało wpisane przez redaktora cyklu np. przymierze, jakie Dawid zawarł z Jonatanem (1 Sm 18,1-23,18), Saulem (24,9-23; 26,17-25), Akiszem (27,1-28,2), mieszkańcami Judy (2 Sm 2,4-5), Abnerem (3,12-21) czy starszymi Izraela (5,1-3). Na tym politycznym tle został ukazany motyw męskiej i żeńskiej zażyłości, miłości i wsparcia dla osoby i działań syna Jessego. Wpierw pokochał go Saul (1 Sm 16,21), potem Jonatan $(18,3 ; 20,17)$, Mikal $(18,20.28)$, słudzy Saula $(18,22)$ i cały lud Judy i Izraela $(18,16)$. Rosnący militarno-polityczny autorytet Dawida, budzący szacunek i lojalność coraz szerszych kręgów społecznych, jest wyrażany językiem przymierza (miłości), którego ślady są obecne w dyplomacji królewskiej całego starożytnego Bliskiego Wschodu.

Rys takiego męskiego braterstwa (broni) w kręgach królewskiego dworu Saula, które nie jest zorientowane na intymność relacji Jonatana i Dawida, lecz na szeroko rozumiane dobro ich rodów (Beniamina i Judy) i całej społeczności Izraela, widać wyraźnie w materiale źródłowym 1 Sm 18,1-21,1; 23,16-18; 2 Sm 1,19-27 ukazującym ich przyjaźń w kontekście wojny z Filistynami i walki Saula o zachowanie władzy. Jonatan uznaje wagę militarnych zwycięstw syna Jessego i dostrzega w nim odpowiedniego partnera do politycznego przymierza, a zarazem solidnego kandydata do tronu $^{18}$. To na tej płaszczyźnie rozwija się ich osobista więź, która na każdym etapie zostaje podporządkowana społecznemu interesowi Izraela. Stąd narrator ukazuje ją w bliskowschodniej formule przymierza społeczno-religijnego, co widać wodwołaniu się do Boga JHWH (1 Sm 20,8.12-13.23.42; 23,16-18), który jest przywołany przez obu młodzieńców jako świadek podnoszący rangę ich umowy i gwarantujący jej nieodwołalność. W kluczu ideowo-religijnym ukazuje się też gest Jonatana przeka-

17 Cykl 1 Sm 16,1 - 2 Sm 5,5 obfituje w opisy relacji Dawida, które mają podtekst emocjonalny i militarno-polityczny (Samuel, Saul, Jonatan, Akisz), ale też uczuciowy, intymny i seksualny (Abigail, Merab i Mikal).

18 To braterskie przymierze jest ukazywane w 1 Sm 18-20 na różne sposoby: jako umowa między równymi sobie partnerami $(20,23.42)$ i zależność między suzerenem i wasalem (wzorzec hetycki): Dawid podporządkowany jest Jonatanowi w 20,8.41, zaś Jonatan Dawidowi w 20,14-16; 23,17-18. W tym świetle niejasny jest tekst 20,17, który sugeruje, że Jonatan jest równy, a zarazem poddany Dawidowi (perspektywa politycznej przyszłości). 
zującego Dawidowi swe książęce szaty i oręże $(18,4)^{19}$. To nie tylko spontaniczny akt bezinteresownej sympatii dla Dawida, ale symboliczny znak dający mu wsparcie polityczno-militarne i gwarantujący lojalność (por. $2 \mathrm{Krl} \mathrm{11,10).} \mathrm{Więź} \mathrm{młodzieńców} \mathrm{od}$ początku cyklu ma charakter oficjalny, nie jest skrywanym przed otoczeniem związkiem intymnym, lecz formą dostrzeganego powszechnie braterstwa $(20,3)$, które daje synowi Jessego gwarancję militarnej ochrony przed Saulem i prowadzi do szerokiej promocji jego imienia na królewskim dworze. Zgodnie z linią narracyjną prezentowaną na kolejnych etapach 1 Sm 16,1 - 2 Sm 5,5, słowa i gesty Jonatana wobec Dawida należy odczytywać w kluczu jego społeczno-religijnej dojrzałości i odpowiedzialności za kraj. Widząc u Dawida charyzmat przywódcy i oceniając jego sukcesy społeczno-militarne w kategorii wybraństwa Bożego (1 Sm 16,1-13.14; 19,4-5; 20,13), syn Saula szybko dostrzega $\mathrm{w}$ nim następcę tronu i postanawia go chronić przed zawiścią ojca. Z czasem jego przyjaźń z Dawidem wykracza poza ramy zwykłej męskiej zażyłości i solidarności. W kolejnych odsłonach sekcji 18,1-23,18 nabiera wymiaru społeczno-religijnego $(20,13.42)$, a osobiste emocje, odczucia i decyzje bohaterów, za aprobatą JHWH $(18,12.14$; por. $2 \mathrm{Sm} 5,10.12)$, zostają podporządkowane dobru narodu (1 Sm 20,4.41-42; 23,16-18).

Analiza struktury 1 Sm 16,1 - 2 Sm 5,5, której integralną, ale nie wiodącą częścią jest sekcja opowiadająca o więzi młodzieńców (1 Sm 18,1-21,1), dowodzi, że celem tego segmentu księgi było odtworzenie procesu transformacji ustroju w Izraelu w kluczu zbawczej asystencji Boga, a nie emocjonalno-uczuciowej relacji jej bohaterów. Nadawanie tej kwestii nieproporcjonalnie dużej wagi na pewno nie idzie w parze z oryginalną strategią narracyjną wypływającą z tych źródeł. Innym istotnym problemem, który należy rozstrzygnąć już na wstępie badań, jest dobór właściwej interpretacji biblijnych źródeł. Ukazując model męskiej zażyłości w 1 Sm 18,1 - 2 Sm 1,27, trzeba pamiętać, że winien odpowiadać on literackim, historycznym, kulturowym i teologicznym założeniom kolejnych redaktorów tego bloku tradycji. Promowana w niektórych publikacjach nieuzasadniona metodologicznie i merytorycznie lektura tych tekstów w perspektywie relacji homoseksualnej jest obca profilowi Ksiąg Samuela i innych źródeł Biblii. Więź młodzieńców ukazywana jest w tym zbiorze źródeł w konwencji historiozbawczego przymierza, przez które realizuje się wola JHWH wobec Izraela. Jej obraz nie może być zatem arbitralnie zredukowany tylko do sfery emocjonalno-uczuciowej, którą nadto przedstawia się a priori w ambiwalentnym zwierciadle relacji intymnej. Przerysowane seksualnie i wzorowane na obowiązujących obecnie kryteriach socjologiczno-psychologicznych pojęcie męskiej przyjaźni zupełnie nie przystaje do modelu starotestamentowego. Biblijne normy prawne

19 Pro-dawidowy redaktor tak relacjonuje bieg zdarzeń, by usprawiedliwić przejęcie władzy przez syna Jessego i ród Judy. Stąd w cyklu są aż dwie jednobrzmiące sceny przekazania oręża i szat królewskich Dawidowi. Wpierw w 1 Sm 17,38-39 czyni to Saul, a potem w 18,4 Jonatan. Sceny te wpisują się w ideowo-teologiczny podtekst czynności symbolicznej Samuela, zapowiadającej wyrwanie władzy z rąk Saula $(15,27-28)$. 
w kwestii praktyk homoseksualnych są bowiem klarowne i jednobrzmiące. Bo choć regulacje z Kpł 18,22; 20,13 są późniejsze niż pierwotna i deuteronomistyczna re-

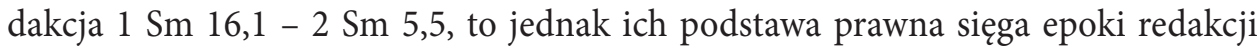
Ksiąg Samuela ${ }^{20}$, a niewykluczone, że nawet czasów Dawida. Inne teksty biblijne (Rdz 19,1-29; Sdz 19,11-30), które uznaje się za starsze od prawa kapłańskiego, promują bowiem tę samą ocenę postaw homoseksualnych. Sugerowanie postawy neutralności, a nawet przychylności ze strony redaktorów sekcji 1 Sm 18,1-21,1 dla orientacji homoseksualnych czy konkretnych czynów i postaw homoseksualnych byłoby negacją etyczno-moralnych podstaw pism starotestamentowych ${ }^{21}$. Kolejne sekcje bloku 1 Sm 16,1 - 2 Sm 5,5 ani razu nie poruszają kwestii moralnej oceny więzi młodzieńców, co - w myśl etycznych standardów obowiązujących w Biblii Hebrajskiej (por. 2 Sm 11,1-12,25; 13,1-21) - sugeruje jej poprawność (por. 1 Sm 20,24-34), natomiast całą uwagę koncentrują na jej społeczno-politycznym podłożu $(20,31)$.

Argumentem za aseksualną koncepcją więzi Dawida i Jonatana są informacje o ich stałych heteroseksualnych związkach i brak jakichkolwiek aluzji do homoseksualnych relacji z innymi osobami. Księgi Samuela i Królewskie mówią o małżeństwach królów i pretendentów do tronu. W badanym materiale źródłowym mowa jest o żonach, synach i córkach Saula (1 Sm 14,49-50; 18,17-29; 2 Sm 6,20-23; 21,1-14), potomnych Jonatana (1 Sm 20,42; 2 Sm 9,1-13), a także żonach, nałożnicach i dzieciach Dawida (Mikal w 1 Sm 18,27; Abigail w 1 Sm 25,15.42; 2 Sm 3,3; Achinoam w 2 Sm 3,2, Maaka w 2 Sm 3,3; Chaggita i Abitala w 2 Sm 3,4; Egla w 2 Sm 3,5; Batszeba w 2 Sm 11,2-12,25; $1 \mathrm{Krl}$ 1,11-31; Abiszag w $1 \mathrm{Krl}$ 1,2-4 i inne w 2 Sm 5,13; 16,22). W kluczu biblijnych norm społeczno-moralnych i religijnych, te informacje wykluczają homoseksualną orientację pretendentów do tronu ${ }^{22}$, ale według dziś obowiązujących kryteriów psychologiczno-socjologicznych mogą być, co najwyżej, pośrednim na to dowodem.

W ocenie źródeł o relacji łączącej Dawida z Jonatanem trzeba wziąć również pod uwagę bardzo pochlebny wizerunek tych postaci w Biblii Hebrajskiej. Obaj funkcjonują w niej jako figury doskonałych przywódców i wojowników ${ }^{23}$, nawet w świetle takich przekazów, jak: 1 Sm 14,24-46; 2 Sm 11,1-12,25 czy 24,1-25, które rzucają cień

20 Motyw bliżej nieokreślonej nieczystości rytualnej w 1 Sm 20,26 sugeruje istnienie regulacji prawnych w dziedzinie moralnej i kultycznej już w epoce rodzącej się monarchii. Jednakże prawne kodyfikacje w zakresie czystości rytualnej i seksualnej, utrwalone w Prawie świętości (Kpł 17-26) i innych sekcjach Księgi Kapłańskiej (7,20-21; 15,16-18), w okresie redakcji Ksiąg Samuela jeszcze nie obowiązywały. Gagnon, The Bible and Homosexual Practice, 229-239.

21 Köstenberger - Jones, God, Marriage, and Family, 67.

22 Choć Biblia nie precyzuje norm prawnych, które zamykałyby homoseksualistom drogę do władzy, to jednak w całym okresie teokracji i monarchii rolę wodza w Izraelu powierza się tylko tym mężczyznom, którzy w obrębie małżeństwa mogą zapewnić ciągłość i stabilność sprawowanej władzy (por. struktury klanowe w epoce patriarchów i instytucję dynastii królewskiej).

23 Tę pochlebną ocenę podzielają teksty starotestamentowe, literatura rabiniczna i Nowy Testament. Zehnder, „Observations on the Relationship”, 169-170. 
na ich moralną nieskazitelność. W przypadku Dawida należy wziąć pod uwagę też pro-monarchiczny i prorocki nurt mesjanizmu, którego ostatecznym wypełnieniem jest osoba i zbawcza misja Jezusa Chrystusa. W myśl religijno-moralnych standardów Biblii, tak pochlebna ocena byłaby niemożliwa, gdyby w tle pozostawała homoseksualna orientacja czy postawa tych bohaterów ${ }^{24}$.

Przed literacką i teologiczną analizą źródeł będących przedmiotem badawczym tej publikacji, a zarazem płaszczyzną sporu przedstawicieli egzegezy tradycyjnej i tych, którzy na wszelkie sposoby doszukują się w nich postaw i orientacji homoseksualnych, trzeba jeszcze poruszyć kwestię metodologii. Sugerowana przez niektórych homoerotyczna interpretacja 1 Sm 18,1 - 2 Sm 1,27 opiera się na kilku założeniach niezgodnych z klasyczną koncepcją egzegezy biblijnej. Pierwszym jest pominięcie oryginalnego historiozbawczego kontekstu Ksiąg Samuela i bezpodstawne narzucenie tekstom biblijnym standardów współczesnej antropologii, socjologii i psychologii, co prowadzi do deformacji idei przyjętych przez ich redaktorów ${ }^{25}$. Drugim metodologicznym błędem interpretacji relacji Dawida z Jonatanem w kategorii więzi homoseksualnej jest nieuprawnione korzystanie z intertekstualnej metody lektury Biblii, które bazuje tylko na terminologicznej analogii porównywanych tekstów, a zupełnie pomija ich specyficzne i precyzyjnie zdefiniowane przez autorów uwarunkowania literackie, historyczne, społeczno-prawne i religijno-kulturowe. Trzecim niedozwolonym w lekturze źródeł biblijnych założeniem jest świadome i tendencyjne wykorzystywanie ich do ilustracji przyjętej wcześniej ideologii, która nie ma nic wspólnego z ich oryginalnym orędziem. W konsekwencji tej lektury biblijny przykład wzorcowej i heroicznej męskiej przyjaźni i braterstwa, opisany 1 Sm 18,1 - 2 Sm 1,27, staje się w publikacjach promujących homoseksualizm koronnym dowodem na otwarcie Biblii Hebrajskiej na związki intymne przedstawicieli tej samej płci.

\section{Analiza kluczowych fragmentów relacji o Dawidzie i Jonatanie}

Pomijając lub łagodząc potępienie czynów homoseksualnych w teologiczno-prawnych (Kpł 18,22; 20,13; Rz 1,26-27; 1 Kor 6,9; 1 Tm 1,10) i narracyjnych tekstach

24 Biblia Hebrajska niejednakowo ocenia czyny heteroseksualne. Jedne surowo potępia (por. Amnon i Tamar w 2 Sm 13,1-22; Dawid i Batszeba w 2 Sm 11-12), inne pozostawia bez negatywnego komentarza (por. Juda i Tamar w Rdz 38,1-30). Jednak żaden jej tekst nie przechodzi obojętnie wobec aktywności homoseksualnej.

25 I tak, zdaniem niektórych promotorów idei homoseksualizmu w 1 Sm 18,1 - 2 Sm 1,27, homoseksualizm Jonatana jest konsekwencją odrzucenia go przez ojca (1 Sm 14,29.36-45; 20,30), który upodobał sobie w Dawidzie $(16,21)$, oraz niepowodzeń w relacjach z kobietami. Lawton, „Saul, Jonathan”, 38-42. Inni są zdania, że to niska samoocena Jonatana była źródłem jego homoseksualnego pociągu i podziwu dla Dawida, cechującego się silną osobowością i odnoszącego sukcesy społeczno-militarne. Comstock, Gay Theology, 83. Pierwsza Księga Samuela nie daje jednak żadnych podstaw do tego rodzaju wniosków. 
Biblii (Rdz 19,1-29; Sdz 19,22-30), promotorzy nowych dróg w egzegezie sugerują rzekomy homoseksualny i homoerotyczny podtekst niektórych jej tradycji. W tym aspekcie zdecydowany prym wiedzie narracja o związku syna Jessego z synem Saula (1 Sm 18,1-3; 19,1; 20,11.17.30.41-42; 2 Sm 1,26). W publikacjach szukających biblijnej aprobaty dla intymnej relacji osób tej samej płci te teksty urastają do roli quasi manifestu programowego. Większość $\mathrm{z}$ nich ma charakter wybitnie ideowy i polemiczny i nie opiera się na rzetelnych badaniach literacko-egzegetycznych tekstów źródłowych. Tylko niektóre, choć w stopniu mocno ograniczonym warsztatowo, odwołują się do analiz literackich, kontekstualnych i narracyjnych oraz metodologii stosowanej w oficjalnej egzegezie biblijnej. Mimo to ich autorzy roszczą sobie prawo do forowania daleko idących wniosków natury światopoglądowej i etyczno-moralnej ${ }^{26}$. Wnioski te wykraczają jednak poza ramy starotestamentowej i nowotestamentowej teologii, a ich naukowa wartość budzi poważne wątpliwości. Według chronologii podanej w 1 Sm 18,1 - 2 Sm 1,27, poniżej zostaną przebadane najczęściej przytaczane przez tych autorów teksty o Dawidzie i Jonatanie, by zweryfikować zasadność ich wniosków w świetle oryginalnej interpretacji sugerowanej w Biblii Hebrajskiej.

\subsection{Rdzeń 'hb w 1 Sm 18,1 - 2 Sm 1,27 (1 Sm 18,1.3; 20,17; 2 Sm 1,26)}

Jednym z czołowych argumentów mających przemawiać za uczuciowo-emocjonalnym i intymnym związkiem obu młodzieńców jest kilkukrotnie użyty w 1 Sm 18,1 - 2 Sm 1,27 rdzeń 'hb ${ }^{27}$ w jego rzeczownikowej ('ahăbāh) i czasownikowej

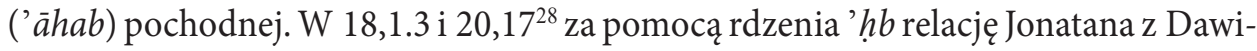
dem określa narrator, $\mathrm{z}$ kolei w 2 Sm 1,26 czyni to sam syn Jessego na wieść o śmierci Saula i jego syna. W Biblii Hebrajskiej 'hb „miłować, kochać, upodobać sobie”29 występuje w wielu kontekstach, określając bliskie związki osób płci przeciwnej, które

26 Najbardziej kontrowersyjne, choć odwołujące się do metodologii egzegezy biblijnej tezy w tej materii proponują: Ackerman, When Heroes Love, 166-168; Gunn, The Fate of King Saul, 93; Harding, „Opposite Sex Marriage a Biblical Ideal?", 35-52; Horner, Jonathan Loved David, 26-39; Hentschel, 2 Samuel, 8; Naumann, „David und die Liebe”, 51, 54, 63; Peleg, „Love at First Sight?”, 171-189; Römer - Bonjour, L'homosexualité, 72-79, 100-101; Horst, Jonathan's Loves, 19-78; Schroer - Staubli, „Saul, David, and Jonathan”, 22-36; Sakenfeld, „Love”, 375-381; Satlow, „They Abused Him Like a Woman”, 1-25.

27 Schroer - Staubli, „Saul, David, and Jonathan”, 27. Rdzeń ten pojawia się jednak we wszystkich typach literatury starotestamentowej i źródłach pochodzących z każdego etapu edycji Biblii. Jego semantyczne pole jest szerokie i zależy od konkretnego kontekstu, w którym występuje. Wersja czasownikowa 'ăhab „kochać” występuje w Biblii Hebrajskiej w różnych koniugacjach (140 razy w qal; 36 razy w formie imiesłowu qal „kochający, przyjaciel”; raz w formie pasywnej nifal „kochany” i 16 razy w formie imiesłowu piel „ukochany, luby, mily”). W formie rzeczownikowej 'ahăbāh „miłość” i jej wariantach rdzeń powraca w Biblii 54 razy. Bergman - Haldar - Wallis, „'āhab”, 102.

28 Składnia tekstu hebrajskiego $1 \mathrm{Sm}$ 20,17b jest ambiwalentna i pozwala tak Jonatana, jak i Dawida uznać za podmiot formy 'ăhēbô „kochał go". Wersja LXX sugeruje wprost, że chodzi o miłość Jonatana do Dawida, tak jak w 1 Sm 18,1.3. Na takie rozwiązanie wskazuje również najbliższy kontekst sekcji 1 Sm 20,1-21,1.

29 Etymologia rdzenia jest niejasna. Łączy się ją z arabskim habba „oddychać z trudem, wzdychać, być podnieconym” lub z arabskim 'ihāb „skóra” (por. Pnp 3,10). Bergman - Haldar - Wallis, „'āhab”, 102. 
mają podtekst uczuciowy, intymny i seksualny (Rdz 24,67; 29,18.30.32; $\operatorname{Sdz} 14,16$; 16,4.15; $1 \mathrm{Sm} \mathrm{1,5;18,20;} 2 \mathrm{Sm}$ 13,1.4; Oz 3,1). Rdzeń ten wyraża jednak relacje zupełnie pozbawione tego podtekstu, np. więzi łączące: ojca i syna ( $\operatorname{Rdz} 22,2 ; 25,28 ; 37,3)$, matkę i syna (Rdz 25,28) czy synową (Rt 4,15), mistrza i ucznia (Prz 9,8), sługę i jego pana (Wj 21,5; Pwt 15,15) czy też żołnierzy i ich militarnego wodza (1 Sm 18,16.22). Korzeń ' $h b$ definiuje również nakazaną przez prawo życzliwość, z jaką Izraelici winni się odnosić do rodaków (Kpł 19,18) i obcych (Kpł 19,34; Pwt 10,18-19), a nade wszystko relację, która winna łączyć ich z Bogiem (Ps 47,5; Jr 2,2; Oz 11,4) ${ }^{30}$, i stosunek, w jakim Bóg pozostaje do Syjonu (świątyni), prawa, sprawiedliwości i sprawiedliwych (Ps 33,5; 37,28; 78,68; 87,2; 146,8; Prz 8,17; Ml 2,11) ${ }^{31}$. W odniesieniu do relacji uczuciowej przedstawicieli tej samej płci Biblia stosuje go przeważnie do mężczyzn $(1 \mathrm{Krl} 5,15)^{32}$. Z taką sytuacją lektor spotyka się w przypadku Saula i Dawida (1 Sm 16,21) oraz Jonatana i Dawida (1 Sm 18,1.3; 20,17; 2 Sm 1,26). W tych sytuacjach ani razu nie sugeruje się intymnego (seksualnego, erotycznego) sensu ' $h b$, który jest natomiast wyraźnie widoczny w Pieśni nad Pieśniami relacjonującej miłosną więź oblubieńca i oblubienicy $(1,7 ; 3,1-4)^{33}$. Poza Pieśnią nad Pieśniami podtekst erotyczny (seksualny) pojęcia 'ahăbāh pojawia się jeszcze w historii Jakuba i Racheli (Rdz 29,20), Amnona i Tamar (2 Sm 13,15; por. 13,1) i sapiencjalnej definicji miłości mężczyzny do kobiety z własnego ludu (Prz 5,18-19). Co ważne, żaden z tekstów relacjonujących wątek intymnej miłości za pomocą rdzenia ' $h b$ nie odnosi się do relacji przedstawicieli tej samej płci.

W Księgach Samuela rdzeń ' $h b$ określa nie tylko relację Dawida do Jonatana, ale też do jego społeczno-politycznych sojuszników, a nawet wrogów (1 Sm 16,21; 18,16; 2 Sm 19,7; por. Ps 109,4-5). W tych miejscach nie przybiera on tonu intymnego, jak w tekstach o jego relacjach z kobietami (1 Sm 18,20;

30 Teologiczny aspekt ' $h b$ jest szczególnie widoczny w biblijnej koncepcji przymierza JHWH z Izraelem (ukazanej w Pwt 4,37; 10,12; 11,13.22; 19,9; 30,6) i literaturze deuteronomistycznej (Joz 22,5; 23,11).

31 Teksty Biblii odnoszą czasownik 'āhab i rzeczownik 'ahăbāh zazwyczaj do osób zajmujących wysoką pozycję w hierarchii społeczno-politycznej i religijnej (JHWH, rodzic, mężczyzna). Podmiotem miłości jest więc w Biblii najczęściej mężczyzna, a kobieta, dziecko czy Izrael to obiekty miłości. Wyjątkiem w tej materii jest Mikal w relacji do Dawida (racje polityczne i mezalians: córka króla i pasterz, giermek; por. 1 Sm 18,20.28) oraz oblubienica z Pieśni nad Pieśniami. Z tego względu w relacji męskiego braterstwa Jonatana z Dawidem podmiotem miłości jest Jonatan, zajmujący wyższą pozycję w drabinie społeczno-politycznej (syn króla i następca tronu; 1 Sm 18,1.3; 20,17; por. 2 Sm 1,26). Ackerman, „The Personal Is Political”, 437-458.

32 Rzadkim biblijnym przykładem miłości (przyjaźni) żeńskiej jest więź Rut i Noemi (Rt 4,15). Wbrew opiniom niektórych egzegetów, tekst Księgi Rut w żadnym razie nie przypisuje jej aspektu intymnego i seksualnego.

33 Księgi Samuela i Pieśń nad Pieśniami odbiegają od siebie formą literacką i kontekstem historycznym (społeczno-kulturowym), narracyjnym i teologicznym. Poza zbieżnością niektórych terminów, nie mają ze sobą wiele wspólnego. W tym świetle mocno dyskusyjne jest więc szukanie tematycznej, teologicznej czy literackiej zależności między intymną więzią oblubieńca i oblubienicy z Pieśni nad Pieśniami a biblijną wersją braterstwa Jonatana i Dawida. Trudne do akceptacji jest już samo zestawianie tak różnych od siebie modeli miłości (przyjaźni) hetero- i homoseksualnej, czego nie chcą przyjąć propagatorzy homoseksualnego podtekstu w 1 Sm 18 - 2 Sm 1. 
por. 2 Sm 13,4; $1 \mathrm{Krl}$ 11,1), lecz wyłącznie społeczno-polityczny czy militarny ${ }^{34}$. I ta właśnie linia interpretacji odpowiada literackiej i ideowo-teologicznej specyfice materiału źródłowego 1 Sm 16,1 - 2 Sm 5,5 w rekonstrukcji więzi łączącej Dawida $\mathrm{z}$ Jonatanem ${ }^{35}$. Ten motyw pojawia się pierwszy raz w tekście podsumowującym walkę Saula z Filistynami (18,1-4), w której Dawid zatriumfował nad Goliatem z Gat (17,1-54; por. $2 \mathrm{Sm} 21,19$; 2 Krn 20,5) ${ }^{36}$. W efekcie tego zwycięstwa między walecznym i odważnym synem króla (14,1-46) a wchodzącym na jego dwór synem Jessego (16,1-13; 16,14-23; 17,1-58) zrodziły się braterstwo i przyjaźń, których intensywność narrator już w 18,1 wyraża pojęciami: qāšar „związać się, przylgnąć, zrosnąć się, zjednoczyć" ${ }^{\prime 37}$, nepeš „życie, dusza, osoba, duch, wnętrze, pragnienie, pasja, emocja” i 'āhab „kochać, miłować" ${ }^{38}$, a w 18,3 potwierdza frazą: wajjikrōt jehônātān wedāwî̀d $b^{e} r \hat{\imath} t b^{e}$ 'ahăbātô 'ōtô $k^{e} n a p s ̌ \hat{o}$ „, zawarł przymierze ${ }^{39}$ Jonatan z Dawidem w swej miłości do niego, [kochał go] jak samego siebie". Sens i liczba tych pojęć w 18,1.3 jest zdaniem niektórych badaczy - argumentem przemawiającym za tym, by określić tę relację jako intymną (homoerotyczną, homoseksualną). Ale czy tak jest naprawdę? W świetle metody historyczno-krytycznej taka lektura tekstu napotyka na szereg poważnych trudności.

34 Sakenfeld, „Loyalty and Love”, 215-230; Brueggemann, „Narrative Coherence in 1 Samuel 18”, 235; Ackroyd, „The Verb Love”, 213-214; Dietrich, The Early Monarchy in Israel, 61.

35 W opinii wielu egzegetów, opisaną w 1 Sm 18 - 2 Sm 1 relację Jonatana do Dawida można interpretować w świetle miłości Boga do Izraela, zilustrowanej w teologii deuteronomicznej (por. Pwt 5-11) tym samym rdzeniem ' $h b$. Zob. Arnold, „The Love-Fear Antinomy”, 551-569. W tym historiozbawczym kontekście zyskuje ona status zupełnie aseksualny, stając się jednym z przejawów miłości i łaskawości JHWH wobec Izraela i Dawida. Pro-dawidowi redaktorzy Pierwszej i Drugiej Księgi Samuela sugerują, że Bóg posłużył się wiernością, bezinteresownością i braterstwem Jonatana, by doprowadzić Dawida do władzy w Izraelu, wyzwolić spod panowania Filistynów rozbite i poróżnione ze sobą pokolenia izraelskie i zjednoczyć je w spójny organizm państwowy. Stoebe, Das erste Buch Samuelis, 347-348. Ta przyjaźń ma status wzorcowej męskiej zażyłości o podtekście ideowo-teologicznym.

36 Z nieznanych powodów pro-dawidowa Septuaginta opuszcza całą scenę $1 \mathrm{Sm}$ 18,1-5.

37 Nigdzie w Biblii qāšar nie czyni aluzji do relacji homoseksualnej, co najwyżej do więzi emocjonalno-uczuciowej podyktowanej wyjątkową sytuacją społeczno-polityczną lub militarną. W tych tekstach ma zwykle znaczenie „uknuć spisek, zawiązać przymierze, zawrzeć umowę, potajemnie się układać” (1 Sm 22,8.13; $1 \mathrm{Krl}$ 16,16; $2 \mathrm{Krl}$ 11,14; 12,21; 15,30; Iz 8,12; Jr 11,9; Ez 22,25; Am 7,10).

38 Oto hebrajska wersja tej redakcyjnej oceny: wenepeš jehônātān niquše râ benepeš dāwid (wajje' ěhābô) [wajje’ ěhābēhû] jehônātān ke nap̌šô „i dusza (życie) Jonatana związała się z duszą (życiem) Dawida. I pokochał go Jonatan jak siebie samego (swe życie, duszę)". Z uwagi na to, że termin 'āhab nie definiuje w Biblii ani razu intymnej relacji przedstawicieli tej samej płci, trudno jest przyjąć, że w 1 Sm 18,1 i 20,17 oraz w 18,3 i 2 Sm 1,26 komunikuje on tego typu treści. Bergman - Haldar - Wallis, „’āhab”, I, 105.

39 Niektórzy interpretują termin berît w 1 Sm 18,3 jako formułę małżeństwa homoseksualnego. Römer Bonjour, L'homosexualité, 73. To sugestia zupełnie nieuprawniona. Biblia wielokrotnie określa tym terminem ugody między mężczyznami, ale nigdy nie sugeruje ich intymnego charakteru (Rdz 14,13; 21,27; 26,28; 31,44; 2 Sm 3,13; 1 Krl 5,26; 15,19; 20,34). W przypadku Dawida i Jonatana pojęcie ma wyraźne konotacje militarne i polityczne, komunikując ideę wzajemnego wsparcia i solidarność pretendentów do tronu. Ten wydźwięk pojęcia widać w literaturze aramejskiej, fenickiej, asyryjskiej i ugaryckiej. Rowe, Sons of Lovers, 43-44, 129, 133-136. 
Biblia Hebrajska za pomocą syntagmy 'ōhēb nap̌šo „miłuje swe życie, duszę, samego siebie" (Prz 19,8) i analogicznych formul ${ }^{40}$ określa też relacje zupełnie aseksualne, np. umiłowanie mądrości i rozsądku ${ }^{41}$, czy bliskie więzi pokrewieństwa w obrębie rodziny i klanu. Ponadto pole semantyczne tych terminów można określić precyzyjnie tylko w ścisłej korelacji z ich najbliższym i dalszym kontekstem literackim, historycznym (kulturowo-religijnym) i ideowo-teologicznym, czego nie biorą pod uwagę propagatorzy idei homoseksualizmu w Biblii. W ich opinii kluczo-

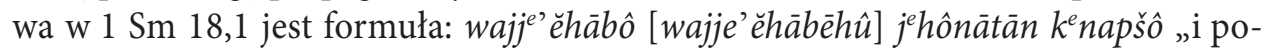
kochał go Jonatan jak samego siebie”. Formuła ta w kontekście wiersza 2 Sm 1,26, a nade wszystko Pnp 1,7; 3,1-4², w których figuruje również rdzeń ' $h b$ i rzeczownik nepeš, przesądza o intymnym (erotycznym i seksualnym) podłożu więzi Jonatana z Dawidem ${ }^{43}$. Istotnie wiersze 18,1 i 18,3 używają czasownikowej i rzeczownikowej formy ' $h b$, akcentując intensywny i emocjonalno-uczuciowy wymiar relacji młodzieńców, ale nie dają bezpośrednich przesłanek, by uważać ją za intymną i sek-

40 W Rdz 44,30 syntagma qāšar + nepeš określa relację, która łączyła Jakuba z jego najmłodszym synem Beniaminem: $w^{e} h a n n a^{\prime} a r$ [...] wenapš̂̀ qušûrâ benapšô ,a chłopca [nie byłoby z nami, którego] życie jest ściśle związane z jego [Jakuba] życiem".

41 Przykładem tej idei może być mądrościowa sentencja z Prz 19,8: qōneh-llēb 'ōhēb napšsô šōmēr tébûnāh limșō'-țôb „Nabywający rozsądku (rozwagi), miłuje swe życie (swą duszę, samego siebie), strzegący roztropności znajdzie szczęście".

42 Zestawianie tych samych lub analogicznych terminów biblijnych i formułowanie ogólnych wniosków o ich wspólnym polu semantycznym czy wymowie teologicznej bez precyzyjnego odniesienia do konkretnego kontekstu literackiego i historycznego, w którym funkcjonują, jest w egzegezie niedopuszczalne. Stąd wnioski, do jakich dochodzą - tylko na bazie obecności tych samych pojęć w Pierwszej i Drugiej Księdze Samuela i Pieśni nad Pieśniami - Silvia Schroer i Thomas Staubli („Saul, David, and Jonathan, 22-36) i im podobni komentatorzy, są nie do przyjęcia. Analiza specyfiki literackiej tych źródeł prowadzi do wniosku, że między figurującymi w nich ' $h b$ i nepeš zachodzi tylko paralelizm syntagmatyczny (analogiczna kombinacja pojęć), brakuje zaś pokrewieństwa syntaktycznego (podobna składnia, która sugeruje

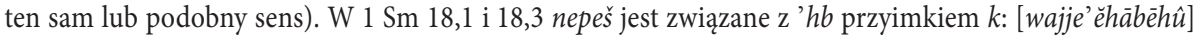
jehônātān $k^{e} n a p$ šô, tworząc formułę przysłówkową o znaczeniu porównawczym ,jak swą duszę (życie, siebie samego)". W Pnp 1,7 i 3,1-4 nepeš jest podmiotem czasownika 'āhab, stąd cała fraza brzmi: še' āhăbāh napšì „którego ma dusza kocha”. Ponadto nepeš w obu przypadkach posiada inny sufiks, który wskazuje na inny punkt odniesienia. W 1 Sm 18,1 występuje z sufiksem 3 os. l.p., co sugeruje, że narrator odnosi się do Jonatana i mówi o jego miłości, zaś w Pnp 1,7; 3,1-4 z sufiksem 1 os. l.p., co przesądza o tym, że miłość oblubienicy odnosi się wprost do oblubieńca. Związek gramatyczny syntagmy 'hb i nepeš w 1 Sm 18,1 i Pnp 1,7; 3,1-4 jest więc luźny i nie wskazuje na to samo znaczenie w obu kontekstach. Promujący homoseksualny podtekst tych tradycji (np. Launderville, Celibacy in the Ancient World, 174-176) nie zauważają, że w tej materii o wiele bliższym znaczeniowo dla 1 Sm 18,1.3 jest tekst Kpł 19,18 o miłości bliźniego. Jedyną różnicą jest to, że przysłówkową formułę porównawczą kenapšô w $1 \mathrm{Sm}$ 18,1.3 zastępuje synonimiczna formuła kāmôkā (jak siebie /ciebie/ samego). W obu tekstach czynność kochania odnosi się do tego samego podmiotu. Właściwą biblijną paralelą dla męskiej miłości w $1 \mathrm{Sm}$ 18,1.3 byłby zatem imperatyw moralny z Kpł 19,18, nakazujący miłość bliźniego. Ta lektura wpisuje się w przychylne dla Jonatana tło sekcji 1 Sm 18,1-21,1, ukazując go jako wzorowego Izraelitę, który wypełnia prawo, miłując swych rodaków.

Ackerman, When Heroes Love, 192-198; Linafelt, „Private Poetry”, 522-525. 
sualną ${ }^{44}$. Bliski kontekst 18,1-3, wiersz 18,16, używa 'àhab na opisanie relacji Judy i Izraela do Dawida: $w^{e} k o l-j i s ́ r a ̄ ' e \bar{l}$ wîhûdāh 'ōhēb 'et-dāwîd kî-hû' jộsē' wābā' lipnêhem „a cały Izrael i Juda kochali Dawida, gdyż wychodził i wracał przed nimi (na ich czele)", ale czyni to w tonie militarnym i społeczno-politycznym. Kontekst 18,16 wyklucza więc intymne (erotyczne) znaczenie rdzenia ' $h b$, co więcej, sugeruje, by również wierszom opisującym relację Jonatana i Dawida nadać ton polityczny i militarny, który dominuje w 1 Sm 16,1 - 2 Sm 5,5. W świetle 18,16 deklarowana w 18,1.3 i 20,17 bezinteresowna i całkowita miłość Jonatana do Dawida polegałaby na szczerym i hojnym braterstwie oraz wieloaspektowym wsparciu jego dążeń do władzy. Widząc odwagę, męstwo, strategiczne i militarne zdolności Dawida oraz rosnącą popularność w Judzie i Izraelu $(17,26-18,16)$, Jonatan dochodzi do wniosku, że będzie on najlepszym kandydatem do zajęcia miejsca po jego ojcu. Dla dobra rodzącej się monarchii syn Saula rezygnuje z politycznych ambicji i zawiera z Dawidem przymierze, które zagwarantuje pokojowe przekazanie rządów. W tej części cyklu plan Jonatana narrator ukrywa pod terminologią „miłości” i „przymierza”, która powraca regularnie w kolejnych jego odsłonach, akcentując stały wzrost poparcia dla syna Jessego na dworze Saula i w całym państwie. Z 18,5 lektor księgi dowiaduje się, że Dawid: wajjịtab be ênê kol-hā'ām w'gām be ênê 'abdê šă' ûl „,był mile widziany przez cały lud i sługi Saula”, w 18,6-7 słyszy pieśń kobiet chwalących jego zasługi ${ }^{45}$, a w $18,16.20 .22 .28$ ponowne deklaracje miłości i szacunku ze strony obywateli Judy i Izraela, Mikal i dworu króla.

W tym względzie narrator najwięcej uwagi poświęca bliskiej relacji Dawida z następcą tronu - Jonatanem $(19,1 ; 20,3.13-16.17 .23 .30-31.41-42 ; 23,16-18)$. Na społeczno-polityczny podtekst tej więzi wskazuje szereg informacji zawartych w sekcji 18,1-21,1. W 18,4 mowa jest o symbolicznym przekazaniu Dawidowi przez Jonatana szat i atrybutów królewskich, a w relacji z ostatniego spotkania młodzieńców w Chorsza akcentuje się, że syn królewski dokonał aktu abdykacji na rzecz przyjaciela (23,16-18). Historiozbawcze tło braterskiego przymierza podkreślają noty o obecności JHWH we wszystkich przedsięwzięciach militarnych i społeczno-politycznych Dawida w tym okresie $(18,14$ i 20,13$)$. W osobisty i społeczno-polityczny wymiar tej przyjacielskiej relacji wpisuje się też wiersz 2 Sm 1,26, który utrzymany jest w tonie żałobnej pieśni wywołanej śmiercią Saula i Jonatana (1,19-27). I ten

44 Na ten wymiar wskazuje natomiast wyrażona w 1 Sm 18,20.28 rdzeniem 'hb miłość Mikal do Dawida, która okazuje się uczuciem nietrwałym (2 Sm 6,20-23). Być może zmienne uczucie Mikal leży u podstaw wyznania Dawida w 2 Sm 1,26, ale na pewno nie sugeruje idei, że Jonatan w Pierwszej Księdze Samuela przejął jej rolę w związku z Dawidem. Przypisywana mu (zob. Ackerman, When Heroes Love, 194-225; Jobling, 1 Samuel, 98-99) rola zniewieściałego partnera, który świadomie i dobrowolnie podporządkowuje się Dawidowi na polu relacji społeczno-politycznej, militarnej i intymnej, jest sprzeczna z profilem tematycznym księgi $(14,1-45 ; 18,1-21,1 ; 23,16-18 ; 31,1-13 ; 2$ Sm 1,19-27) i strukturą składni hebrajskiej. W 1 Sm 20,17 to on jest podmiotem czasownika ' $h b$, co w myśl schematów biblijnej składni oznaczałoby jego dominację nad Dawidem. 
passus określa w konwencji miłości relację Dawida do poległego w bitwie następcy

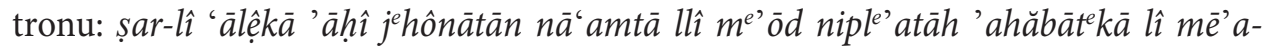
hăbat nāšr̀m „odczuwam żal po tobie, mój bracie Jonatanie. Byłeś mi bardzo drogi. Twa miłość była dla mnie bardziej cudowna /cenna/ niż miłość kobiet”. Ale i tę formułę należy odczytać w społeczno-politycznym i militarnym kontekście, w którym

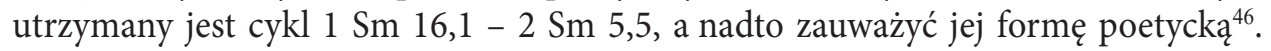
Wszechobecny ideowo-teologiczny aspekt 1 Sm 16,1 - 2 Sm 5,5 wyklucza homoseksualny podtekst wyznań syna Jessego. Ta informacja w kontekście jego walki o tron i Bożych obietnic, które gwarantowały mu trwałość władzy w Izraelu (por. 2 Sm 7; 22,1-23,7; $1 \mathrm{Krl} 2,1-4 \mathrm{a} ; 6,12 ; 11,34$ ), byłaby nie do pogodzenia $\mathrm{z}$ ówczesnymi standardami moralnymi i ideowymi ${ }^{47}$. Autor 2 Sm 1,19-27 i redaktor, który włączył tę pieśń w obręb $1 \mathrm{Sm} 16,1$ - 2 Sm 5,5, chcieli po prostu podać polityczną i militarną apologię syna Jessego. W perspektywie monarchicznych ambicji Dawida i dążeń rodu Judy, by przejąć władzę w królestwie Saula, ich zadaniem nie było określenie seksualnych preferencji pretendenta do tronu, lecz odsunięcie od niego podejrzeń

46 Stoebe, Das zweite Buch Samuelis, 96; Amzallag - Avriel, „Complex Antiphony in David's Lament”, 1-3. Motyw miłości do zmarłego i obrazy opiewające jego zasługi mają w pieśniach żałobnych zwykle postać poetyckiej hiperboli, które wpisują się w ton panegiryku eksponującego wielkość opłakiwanego. Ponadto syntagma 'ahăbat nāšìm „miłość kobiet” ma w tym wierszu sens dość ambiwalentny, gdyż może odnosić się do kobiecego przywiązania do męża (podtekst erotyczny i seksualny) lub oddania dzieciom (bez takiego podłoża). Anderson, 2 Samuel, 19. W 2 Sm 1,26 Dawid odnosi się do miłości kobiecej w ogólności, a nie do własnego uczucia do kobiet, z którymi wiązały go relacje intymne (seksualne). Zresztą wiersz 1,23 w kategorię miłości (braterstwa, przyjaźni) wpisuje jego więź z Jonatanem i Saulem: šă ûl wîhônātān hanne ěhābîm wehann ${ }^{e ` i ̂ m i ̂ m ~ „ S a u l ~ i ~ J o n a t a n, ~ u m i ł o w a n i ~ i ~ d r o d z y ~(u r o k l i w i, ~ p r z y j a z ́ n i) ” . ~ W ~ z e s t a w i e n i u ~ w i e ̨ z i ~}$ Dawida z Jonatanem z miłością do kobiet można upatrywać świadomego zabiegu redaktora księgi, który w ten sposób wyklucza jej intymny (seksualny) charakter. Zehnder, „Observations on the Relationship”, 141. Z kolei promotorzy homoseksualnego klimatu tego passusu postulują jej erotyczny podtekst. Zob. Olyan, „Surpassing the Love of Women”, 10-13, 16. To stanowisko opiera się jednak na kilku błędnych założeniach: 1) nie każda bliska relacja uczuciowa mężczyzny z kobietą czy mężczyzny z mężczyzną ma w Biblii podłoże seksualne (Rdz 19,1-11; Rdz 29,25.30-32; 30,15.20; Sdz 19,11-30; 1 Sm 1,5.8; Prz 31,10-31);

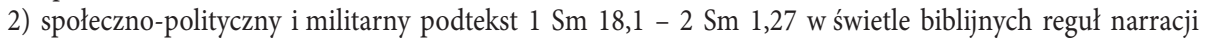
w zasadzie determinuje sposób interpretacji więzi tych młodzieńców i nie pozwala odczytać jej w perspektywie poetyckiego opisu miłosnych zalotów i wynurzeń dwojga zakochanych z Pieśni nad Pieśniami; 3) zbieżność niektórych terminów i wyrażeń jest niewystarczającym argumentem, by przesądzać o przesłaniu porównywanych tekstów, zwłaszcza że pieśń 2 Sm 1,19-27 nie jest wyznaniem miłosnym, tak jak Pieśń nad Pieśniami, lecz żałobnym panegirykiem pretendenta do tronu, wypowiedzianym na cześć zmarłego króla i jego syna (obydwaj są bohaterami wierszy 1,19-25.27); 4) wiersz 2 Sm 1,26 wpisuje się w ton społeczno-politycznej i militarnej ugody Dawida z Jonatanem (1 Sm 18,3; 20,16.42; 23,18) i bliskowschodniej etykiety królewskiego dworu, które obfitowały w symbolikę gestów i słów wyrażających wspólnotę interesów, lojalność i solidarność we wzajemnych relacjach indywidulanych czy zbiorowych; 5) interpretacja formy i treści żałobnej pieśni Dawida w kontekście innym niż ten oryginalny z 1 Sm 16,1 - 2 Sm 5,5, a także narzucanie jej idei typowych dla współczesnej socjologii, psychologii czy kultury, prowadzi zawsze do nieuzasadnionej deformacji biblijnego źródła i intencji jego autorów (redaktorów).

47 McKenzie, King David, 84-85. Wprawdzie norm potępiających czyny homoseksualne brak jest w najstarszych kodeksach prawa Izraela (Wj 20,22-23,33; Pwt 12-26), ale na bazie treści Biblii Hebrajskiej można założyć, że w przestrzeni religijno-moralnej biblijnego Izraela nie było przyzwolenia na związki osób jednej płci. 
o to, że mógł przyczynić się do śmierci Saula, Jonatana oraz pozostałych synów królewskich i jego wysokich urzędników (por. 1 Sm 27,1 - 30,31; 2 Sm 1,1-5,5; 9,1-13; 21,1-14). Stąd pieśń Dawida (2 Sm 1,19-27) jest w całości skoncentrowana na wychwalaniu społeczno-politycznych, ludzkich i militarnych walorów poległego króla i jego syna, a także akcentowaniu motywu szacunku i rewerencji, jakimi syn Jessego darzył obu poległych, którzy broniąc ojczyzny, zostali pobici przez Filistynów. Emocjonalna więź Dawida w całej pieśni dotyczy bowiem obu mężów z rodu Beniamina, a jedyny zadedykowany wyłącznie Jonatanowi wiersz 1,26, który wyróżnia się intensywnością uczuć: nā'amtā llî $m^{e}$ 'ōd niple' atāh 'ahăbāte $k \bar{a}$ lî mè' ahăbat nāš̀m, w duchu poetyckiej metafory i hiperboli akcentuje polityczno-militarną wagę męskiego braterstwa broni, a nie intymny charakter relacji Dawida i Jonatana.

Argumentem za tą lekturą idei miłości młodzieńców jest bliski i dalszy kontekst pieśni o dojściu Dawida do władzy i jego rządach. I tak na przykład tekst 2 Sm 19,7, relacjonując czas rebelii Absaloma przeciw Dawidowi, informuje o jego ostrej kontrowersji z generałem wojsk - Joabem, który zarzuca królowi nielojalność, niesprawiedliwość i polityczną niedojrzałość prowokującą rozpad państwa. To ciężkie oskarżenie świadomie ujmuje w skontrastowane z sobą pojęcia miłości i nienawiści: le'ahăbāh 'et-śonn ệ̂ka weliśnō' 'et-'ōhăbệkā kî higgadtā hajjôm kî̀ ên lekā śärîm wa'ăbādîm „kochasz tych, którzy cię nienawidzą, a nienawidzisz tych, którzy cię kochają, gdyż dziś pokazałeś, że masz za nic dowódców i sługi”. I w tym przypadku miłość Dawida nie ma podtekstu intymnego czy seksualnego, a jedynie polityczno-militarny. W podobnym tonie o miłości Dawida deuteronomista wypowiada się, opisując jego bliską więź z władcą Tyru - Hiramem, który na mocy zawartego wcześniej przymierza wspierał go w budowie struktur pałacowych i świątynnych w Jerozolimie. W $1 \mathrm{Krl}$ 5,15 ta ekonomiczna i polityczna relacja wyrażona jest terminologią miłości znaną z biblijnych i pozabiblijnych źródeł dyplomacji królewskiej ${ }^{48}$ : kî

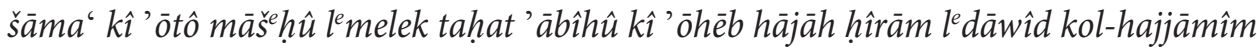
„[Hiram, król Tyru, posłał do Salomona sługi], gdy usłyszał, że namaszczono go na króla w miejsce jego ojca. Hiram pozostawał w miłości (braterstwie, przyjaźni) z Dawidem przez wszystkie dni”.

Na społeczno-polityczny i militarny, a nie intymny wymiar relacji królewskiego syna i Dawida wyrażonej rdzeniem ' $h b$ wskazuje też tytuł 'ahî „mój bracie” w 2 Sm 1,26, wpisujący się w ideologię przymierza typowego dla kręgów królew-

48 Idea miłości jest znakiem rozpoznawczym asyryjskich i babilońskich tekstów dokumentujących ugody i przymierza polityczne. Przykładem takiego tekstu jest np. zapis porozumienia asyryjskiego króla Asarhaddona z jego politycznymi wasalami, w którym zobowiązuje ich do lojalności i posłuszeństwa (miłości) wobec swego syna i następcy tronu - Assurbanipala: „Winniście kochać Assurbanipala, księcia przeznaczonego do urzędu wielkiej korony, syna Asarhaddona, króla Asyrii, waszego pana, jak siebie samych" (6: 266-268). Parpola - Watanabe, Neo-Assyrian Treaties, 39. Podobne zapisy mają archiwa Mezopotamii i Egiptu. Zob. Moran, „Ancient Near Eastern Background”, 77-87; Thompson, „The Significance of the Verb Love", 334-338. 
skiego dworu (pretendentów do tronu), w jakim od początku pozostawali obaj młodzieńcy (1 Sm 18,1;20,16.42;23,18). Takie oficjalne społeczno-polityczne i militarne więzy były w starożytności biblijnej uważane za niezwykle ważne. $Z$ uwagi na ich publiczną doniosłość i użyteczność ceniono je wyżej niż wszystkie inne relacje międzyludzkie, a zatem i te o podłożu emocjonalno-uczuciowym i stricte intymnym ${ }^{49}$. Nic dziwnego, że oficjalny pretendent do tronu, w obliczu śmierci sprawujących dotąd władzę w Izraelu, publicznie gloryfikuje ich zasługi i docenia utracony przywilej bliskiej z nimi więzi, którą wychwala w najbardziej wyszukany i poetycki sposób ${ }^{50}$.

Finalizując tę zwięzłą literacką i intertekstualną analizę rdzenia ' $h b \mathrm{w}$ sekcji 1 Sm 18 - 2 Sm 1, należy stwierdzić, że sugerowana przez propagatorów homoseksualizmu lektura wierszy 18,1.3 i 20,17 jest nieuprawniona. Miłość młodzieńców nabiera w tych tekstach kolorytu społeczno-politycznego. Najstarszy syn Saula, legitymujący się prawem następstwa tronu, doceniając męstwo i militarne predyspozycje Dawida ujawnione w walce $\mathrm{z}$ Goliatem $(17,1-58)$ i podczas misji zleconych przez króla (18,5-30), postanowił językiem dyplomacji wskazać i wesprzeć jego społeczno-polityczne aspiracje i dla dobra narodu zrezygnować z ubiegania się o rządy ${ }^{51}$. Tę lekturę potwierdza wiersz 18,4, opisujący dobrowolne przekazanie przez Jonatana insygniów władzy: płaszcza ( $\left.m^{e \bullet} \hat{\imath} l\right)$ i szaty królewskiej $(\mathrm{mad})$ oraz broni: miecza (hereb), łuku (qešet) ${ }^{52}$ i pasa (hăgor) (por. 1 Sm 13,22) ${ }^{53}$, a także wiersze 20,11-17 i 23,17b. Rozbrzmiewa w nich znów deklaracja następcy tronu, który terminologią miłości i przymierza oficjalnie potwierdza abdykację. Widząc dowody obecności JHWH w życiu

49 W świetle praw religijno-moralnych epoki Dawida i redakcji Pierwszej i Drugiej Księgi Samuela, miłość

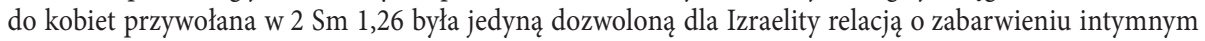
(seksualnym).

50 Mało pochlebną samoocenę własnej relacji do kobiet można tłumaczyć strategią narracyjną Ksiąg Samuela, które w dużej mierze przypominają biografię Dawida. Na tym etapie opowiadania Dawid doświadczył miłości trzech kobiet: Mikal, Abigail (1 Sm 25,3.14-42; 30,5; 2 Sm 2,2; 3,3) i Achinoam (1 Sm 27,3; 30,5; $2 \mathrm{Sm}$ 2,2), które nie odegrały w jego życiu większego znaczenia, a królewska córka - Mikal została nawet przez niego zdyskredytowana i odrzucona (1 Sm 14,49; 18,20.27; 19,11-17; 25,44; 2 Sm 3,13-14; 6,16-23). Z tej perspektywy słowa Dawida z 2 Sm 1,26, w których wyżej ceni przyjaźń z Jonatanem niż miłość kobiet, są poniekąd zrozumiałe.

51 Wskazując na wzorce męskiej relacji w mezopotamskich eposach o Enkidu i Gilgameszu, niektórzy dopatrują się w narracji o Dawidzie i Jonatanie świadomej ambiwalencji terminologicznej i merytorycznej, która ma sugerować erotyczne tło ich związku, by zdyskredytować Jonatana jako następcę tronu (brak męskiego profilu, rola kobieca w relacji z Dawidem). Zob. Ackerman, When Heroes Love, 165-199; Peleg, „Love at First Sight?”, 171-189; Sasson, „Some Literary Motifs”, 270; Michael, „Anger Management and Biblical Characters”, 471-472; Sasson, „Gilgamesh Epic”, 1024-1027; Slawik - Slawik, „Homoseksualizm problemem Kościoła?”, 19-23. Bardziej przekonujące są jednak aluzje do antycznych wzorców społeczno-politycznego i militarnego braterstwa, np. więzi Achillesa i Patroklosa w Iliadzie Homera. Zob. Kaiser, „David und Jonathan”, 281; McCarter, 1 Samuel, 305; Johnson, Reading David and Goliath, 208; Rowe, „Is Jonathan Really David's “Wife”?", 183-193.

52 Niektórzy w hebrajskich pojęciach qešet „łuk” i ḥẹs „strzała” w 18,4; 20,20-22.36-38 i 2 Sm 1,22 widzą absurdalną aluzję do męskiego przyrodzenia Jonatana. Ackerman, When Heroes Love, 183.

53 Gest Jonatana jest oficjalnym uznaniem autorytetu i władzy Dawida w kontekście toczącej się walki o tron w Izraelu. Orly, "David and Jonathan", 9-12; Stansell, "David and His Friends", 123. 
Dawida, które gwarantowały sukcesy w jego społeczno-politycznych i militarnych przedsięwzięciach i były porównywalne z tymi, jakimi cieszył się Saul w początkowej fazie panowania (por 10,7.10; 11,1-15; 13,1-14,52 i 17,1-58; 18,5.12.14-15.28; 19,5.8; 20,13), Jonatan zapowiada rządy syna Jessego (por. 20,14-17.23; 23,17-18) i zawiera z nim przymierze pokoju obejmujące również cały jego ród.

\subsection{Rdzeń ḥpṣ w cyklu tradycji o Dawidzie i Jonatanie (1 Sm 19,1)}

W 1 Sm 19,1 więź Jonatana i Dawida jest opisana także rdzeniem hpṣ „upodobać sobie, związać się, przylgnąć, lubić, kochać", co według niektórych komentatorów ${ }^{54}$ jest sugestią edytora tych tradycji, by rozumieć ją w sensie relacji intymnej: wîhônātān ben-šá $\hat{a}$ u hāpēs $b^{e} d \bar{a} w i d m^{e} \bar{o} d$,a Jonatan, syn Saula, bardzo upodobał sobie Dawida”. W Biblii Hebrajskiej rdzeń ḥpṣ pojawia się 73 razy jako czasownik, 13 razy jako przymiotnik hapeș „lubiany, upragniony, ukochany” i 38 razy jako rzeczownik hepes

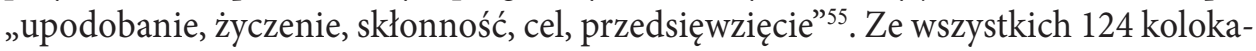
cji żadna nie sugeruje tła homoerotycznego, a tylko sześć formuł hāpēṣ $b^{e}$ „kochać, znaleźć upodobanie, lubić, zapragnąć" wskazuje na intymność (erotyzm) w relacji heteroseksualnej (Rdz 34,19; Pwt 21,14; Pnp 2,7; 3,5; 8,4; Est 2,14) $)^{56}$. Pieśń nad Pieśniami stosuje czasownik hāpeẹs zawsze w tej samej konstrukcji zdaniowej, która wprost nie implikuje związku ze sferą intymną i uczuciową zakochanych: ûmah- $t^{e} \bar{o} r^{e} r \hat{u}$ 'et-hā' ahăbāh 'ad šettehpās , „a na cóż budzić umiłowaną, nim sama zapragnie, by wstać ze snu" (Pnp 8,4). Z powyższego zestawienia jasno wynika, że rdzeń $h p s ̦$ w Biblii Hebrajskiej bardzo rzadko odnosi się do relacji intymnych i nigdy nie dotyczy przedstawicieli jednej płci. Również w 1 Sm 19,1 jego sens nie ma podtekstu erotycznego, co potwierdza najbliższy kontekst narracji. Relacjonując spisek Saula, narrator w 18,22 informuje, że król zachęcał swe sługi, by namawiali Dawida do większej aktywności na dworze królewskim (małżeństwo z Mikal) i działań militarnych (walka z Filistynami). Zgodnie z wolą króla, słudzy w tych rozmowach mieli powoływać się na jego sympatię i życzliwość: hinnēh hạpeẹs bekā hammelek „oto król znalazł w tobie upodobanie", oraz solidarność i wsparcie ze strony królewskiego dworu: $w^{e}$ kol- ăbādâw' ăhēbûkā „a wszyscy jego słudzy cię kochają". Zestawienie w 18,22 dwu podobnych postaw wobec Dawida w tym samym klimacie militarno-politycznym i wyrażenie ich synonimiczną terminologią (' $h b$ i $h p s ̦$ ) w zasadzie wyklucza ich intymne konotacje ${ }^{57}$, a zarazem rzuca światło na związek Jonatana z Dawidem w 19,1.

\footnotetext{
54 Schroer - Staubli, „Saul, David, and Jonathan”, 28-29.

55 Botterweck, "hāpēẹ", 93-94.

56 Botterweck, "hāpēẹ", 95-96.

57 Idąc za metodologią wskazaną przez homoerotyczną lekturę tekstów o Dawidzie i Jonatanie, na bazie już samej obecności rdzeni $h p s$ i ’hb w 18,22 należałoby przypisać Saulowi i jego podwładnym analogiczną postawę intymności wobec syna Jessego (por. 18,16). Gagnon, The Bible and Homosexual Practice, $146-152$.
} 
Saul o sympatii do Dawida mówi bowiem w 18,22 publicznie i w ściśle określonym celu: chce podstępnie sprowadzić śmiertelne niebezpieczeństwo na politycznego konkurenta, który zdobywa coraz szersze poparcie na jego dworze, w armii i pośród ludu, by w ten sposób zabezpieczyć sukcesję tronu dla Jonatana (por. 20,30-31). Zgodnie ze standardami historyczno-krytycznej lektury tekstu natchnionego ten sam sens należy przypisać nastawieniu Jonatana do Dawida w 19,1, skoro jest wy-

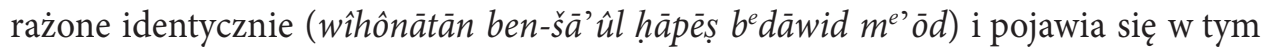
samym kontekście narracyjnym, co w 18,22. W tych dwu passusach hps ma tylko odmienną motywację. W przypadku Saula w rzeczywistości nie chodzi o sympatię króla do Dawida, lecz o podstępne szukanie jego śmierci, do której ma doprowadzić propagowanie fałszywych wieści o rzekomej życzliwości władcy (por. 18,22 i 19,1a). W przypadku Jonatana ta życzliwość i lojalność ma z kolei wymiar na wskroś szczery i żywy. Są one podyktowane jego uznaniem dla Bożego wybraństwa ${ }^{58}$ i osobistych przymiotów Dawida, które czyniły z niego doskonałego przyjaciela i kandydata na następcę tronu w Izraelu. Polityczny podtekst upodobania, jakie Jonatan znalazł w Dawidzie $(19,1)$, można wiązać ze sceną opisaną w 2 Sm 20,11. W chwili skrytobójczego zgładzenia Amasy przez Joaba jeden z jego sług wystosowuje publiczny apel

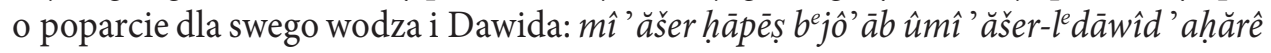
jô' $\bar{a} b$ „kto ma upodobanie w Joabie (jest mu lojalny i wierny) i kto jest za Dawidem, niech idzie za Joabem". W tych tekstach da się wyczuć ewidentny militarno-ideowy podtekst narracyjny, a rdzeń ḥpṣ nie wyraża intymnej więzi z Joabem czy Dawidem, lecz wsparcie dla ich inicjatyw politycznych ${ }^{59}$. Tak więc z 1 Sm 19,1b i 20,11-23 nie wypływa deklaracja intymnego uniżenia i podporządkowania się Jonatana Dawidowi, lecz gotowość okazania daleko idącego wsparcia dla jego monarchicznych aspiracji poprzez konkretne akty solidarności i lojalności, które są typowe dla dojrzałej i trwałej przyjaźni. W jej imię Jonatan ostrzega przyjaciela przed grożącym mu niebezpieczeństwem, zbiera dla niego cenne informacje oraz osobiście wstawia się za nim u króla, aby ocalić jego życie (1 Sm 19,1-21,1 ${ }^{60}$.

Ogólny pro-dawidowy i teologiczny profil cyklu 1 Sm 16,1 - 2 Sm 5,5 pozwala też sądzić, że motyw bliskiej przyjaźni z królewskim synem jest interpretowany

58 Księgi Samuela i Królewskie zawierają też teksty, w których rdzeń ḥpṣ ilustruje ideę umiłowania i upodobania Dawida i Salomona przez JHWH (por. 2 Sm 15,26; 1 Krl 10,9; 2 Krn 9,8).

59 Społeczno-polityczny i militarny podtekst tej przyjaźni widać w scenie 1 Sm 20,12-23, w której - w atmosferze konspiracji przed Saulem czyhającym na życie Dawida - Jonatan oficjalnie rezygnuje ze starań o tron na rzecz przyjaciela i pieczętuje z nim przymierze pokoju. Jego treścią jest wzajemny szacunek i lojalność, które mają trwać nieprzerwanie bez względu na bieg zdarzeń i obejmować rody kontrahentów ugody $(20,16.23)$.

60 O przyjaźni z Jonatanem, jako zdarzeniu powszechnie znanym i akceptowanym na dworze Saula, mówi sam Dawid w 1 Sm 20,3. Więź tę określa w sposób naturalny i typowy dla Biblii, który nie suponuje zna-

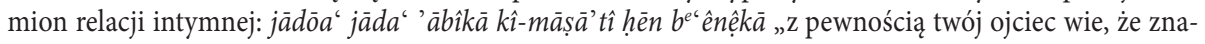
lazłem przychylność (łaskę, życzliwość) w twych oczach”. Zob. Fleming, „Political Favoritism in Saul's Court", 19-34. 
przez narratora jako dowód Bożego błogosławieństwa dla Dawida i potwierdzenie jego Bożego wybraństwa, które zarazem oznacza odrzucenie dynastii Saula. W świetle idei Bożego upodobania w Dawidzie, wyrażonej tym samym rdzeniem hpṣ w 2 Sm 15,26, bliska więź Jonatana z synem Jessego z pewnością nie zyskuje kolorytu relacji homoseksualnej. Upodobanie, jakie Jonatan żywił do Dawida, narrator zestawia bowiem z ideowo-teologiczną ideą wyboru, którym JHWH obdarzył syna Jessego i Salomona. W tej perspektywie jest ono postrzegane jako reminiscencja Bożej łaski dla Dawida i element planu JHWH, który ma doprowadzić go do władzy w Izraelu (1 Sm 20,13-17.23) w miejsce Saula, jego rodu i pokolenia Beniamina $(13,13-15 ; 15,1-35 ; 28,4-25)$. Ta ideowo-teologiczna i pojęciowa spójność obrazu Dawida w Pierwszej Księdze Samuela - jako „umiłowanego przez JHWH i Jonatana” - również wyklucza homoseksualny podtekst treści 19,1. W kluczu teologicznej lektury cyklu, upodobanie Jonatana w Dawidzie należy odczytać jako konkretną formę Bożego upodobania i jeden z istotnych elementów Jego zbawczego planu wobec przyszłego władcy Izraela i Judy. W kolejnych sekcjach cyklu nieprzerwanie się podkreśla, że Dawid w drodze do tronu napotyka na łaskawość Bożą (16,1.12-13; 17,37.45-47; 18,12.14.28) i ludzką (Saul, Jonatan, wiwatujące kobiety, Mikal, lud Izra-

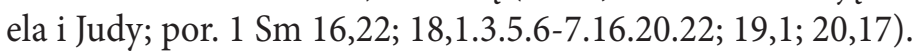

\subsection{Idea przysięgi w relacji Dawida z Jonatanem}

$\mathrm{Na}$ homoseksualny podtekst braterskiej więzi Jonatana i Dawida miałby też wskazywać czasownik šāba $a^{61}$ „przysięgać, zobowiązywać się, zawierać oficjalną ugodę"62, występujący w 1 Sm 20,3.42 i w Pieśni nad Pieśniami (2,7; 3,5; 5,8-9; 8,4). I w tym wypadku należy mówić o nieuprawnionej metodycznie transpozycji znaczeń, którą stosują komentatorzy przenoszący sens i oryginalny kontekst jednej tradycji biblijnej na drugą tylko na podstawie pokrewieństwa etymologii wybranych pojęć czy formuł. Rdzeń $s b^{6}$ występuje w Biblii Hebrajskiej 185 razy. W większości pojawia się w koniugacji nifal "przysięgać" i hifil „nakazać przysięgę, domagać się jej, zaklinać” w obrębie rytualnych błogosławieństw i przekleństw, a także zawieranych w różnych okolicznościach zobowiązań, ugód i przymierzy. Tak jest też w przypadku wierszy $1 \mathrm{Sm}$ 20,3.42 relacjonujących społeczno-polityczne i militarne zobowiązania dwu pretendentów do tronu w Izraelu. Cały sekcja 20,1-21,1 (por. 23,16-18) ma formę przymierza, którego istotą jest uroczysta przysięga wypowiadana $\mathrm{w}$ formie błogosławieństwa (przekleństwa) przez obu lub jednego z kontrahentów zawieranej ugody. W 20,3 taką przysięgę wypowiada Dawid. Jej powodem jest realne zagrożenie jego życia, płynące ze strony Saula, oraz siła zrodzonej w tym czasie więzi z Jonatanem.

61 Kottsieper, „šāba'”, 313.

62 Gerig, Jonathan and David. A Love Story, 111-113. 
Te okoliczności prowadzą młodzieńców do zawarcia zobowiązującej ich umowy, pieczętującej wzajemną i trwałą lojalność i solidarność (19,1-24; 20,1-9.24-42) ${ }^{63}$.

Klimat emocjonalnej przysięgi Dawida z 20,3 udziela się w zobowiązaniu Jonatana w 20,12-13. Przyjmuje ono formę rytualnego przekleństwa: kōh-ja“ăśeh JHWH lîhônātān $w^{e} k \bar{o} h$ jōsîp kî̀ „niech to uczyni JHWH Jonatanowi i tamto doda, jeśli...”, które ma dotknąć syna Saula na wypadek zaniechania deklarowanego uroczyście wsparcia na rzecz przyjaciela. Solidarność i lojalność, wyrażone formułą przysięgi wynikającej z zawartej ugody społeczno-politycznej $(20,16)$, komunikują też wersy 20,17 i 20,42. I one ukazują korzyści, jakie zawarta umowa daje Jonatanowi i Dawidowi. Wiersz 20,17: wajjôsep jehônātān lehašbîa' 'et-dāwid be' ahăbātô 'ōtô kî̀' ahăbat napš̂̀ 'ăhēbô ,i ponownie Jonatan zaprzysiągł Dawida z uwagi na swą miłość do niego, gdyż kochał go jak samego siebie”, podkreśla uroczystą formułę przysięgi, jej motywy i nieodwołalność. Na jej mocy Jonatan zobowiązał się bronić przyjaciela przed gniewem ojca, zrezygnował z ubiegania się o władzę, a w zamian zobligował Dawida do ochrony jego bliskich po objęciu tronu w Izraelu $(20,12-15)^{64}$. Społeczno-polityczny i religijny podtekst przymierza i przysięgi młodzieńców akcentuje też wiersz 20,42: wajjōmer jehônātān ledāwid lēk l'šālôm 'ăšer nišba'nû šenênû 'ănahnû be šèm JHWH „i rzekł Jonatan do Dawida: «idź w pokoju! Niech się stanie to, co przysięgaliśmy my dwaj w imię JHWH, [mówiąc: niech JHWH będzie między mną a tobą, między rodem moim a twoim na wieki]»”. Forma i treść tych wierszy przesą-

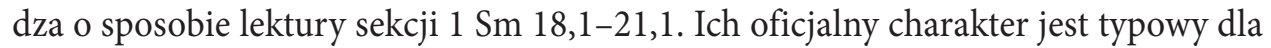
starożytnych umów dwustronnych zawieranych w obecności Boga dla potwierdzenia wzajemnej lojalności.

Do tak zdefiniowanego w Pierwszej Księdze Samuela statusu przysięgi i przymierza nie przystaje treść i kontekst miłosnych deklaracji i zobowiązań, jakie wypowiadają w nadmiarze uczuć i emocji kochankowie w Pieśni nad Pieśniami. Ten miłosny poemat zawiera pięć kolokacji czasownika šāba w koniugacji hifil „domagać się przysięgi, zaprzysiąc, zaklinać kogoś”. Aż trzy z nich wypowiada oblubieniec pod adresem jerozolimskich towarzyszek swej ukochanej, obligując je, by nie budziły jej ze snu: hišba'tî' 'etkem benôt je rûšālaim $[. .].(2,7 ; 3,5 ; 8,4)$. Natomiast raz w ten emocjonalny sposób zwraca się do córek jerozolimskich oblubienica, która poprzysięga je, by szukały jej ukochanego i powiedziały mu o jej głębokiej miłości $(5,8$; por. 5,9). Żaden z tych tekstów nie uprawnia, by wyjątkową formę, treść, kontekst literacki i zwyczajowy formuły przysięgi z Pieśni nad Pieśniami odnieść i utożsamić z tradycjami o społeczno-politycznych i militarnych zobowiązaniach Dawida i Jonatana. Wprawdzie w 1 Sm 20,17 czasownik šāba jest w koniugacji hifil, jak we wszystkich

63 Kottsieper, „šāba ‘", 319, 329-330.

64 W tym samym tonie nieodwołalnego zobowiązania (formuła przysięgi na JHWH) do podjęcia ściśle określonych działań w duchu wierności, wdzięczności lub lojalności wypowiada się Joab do Dawida po klęsce Absaloma (2 Sm 19,8), a także bliscy współpracownicy Dawida podczas wojny z Filistynami, zabraniając mu walczyć, by nie narazić na niebezpieczeństwo jego królewskiego autorytetu (2 Sm 21,17). 
tekstach Pieśni nad Pieśniami, jednak już w 1 Sm 20,3.42 występuje w koniugacji nifal, ilustrującej ideę dobrowolności przysięgi i akcentującej jej wagę i wiarygodność. Ponadto rdzeń šb ani w 1 Sm 20,3.17.24 (por. 20,13-16), ani w żadnym innym miejscu Ksiąg Samuela, nie sugeruje podtekstu intymnego (erotycznego). W sekcji o Jonatanie i Dawidzie posiada on natomiast bardzo silną podbudowę emocjonalną sprowokowaną napiętą sytuacją społeczno-polityczną i militarną (królewski spisek, wojna z Filistynami), która nagle i brutalnie rozdzieliła dwu przywiązanych do siebie przyjació ${ }^{65}$.

\subsection{Podtekst formuły: Iekâ wenēṣē' haśśädeh (1 Sm 20,11)}

Kolejnym argumentem tych, którzy w braterstwie Dawida z Jonatanem widzą przykład więzi homoseksualnej, jest opis ich sekretnego spotkania w szczerym polu ${ }^{66}$ : wajjēṣe' û šenêhem haśśâdeh „i wyszli obydwaj na pole” (20,11b) zaproponowanego przez syna Saula: lekâ $w^{e} n e \bar{s} s \bar{e}$ ' haśśádeh "chodź, wyjdźmy na pole" $(20,11 \mathrm{a})^{67}$. Swą sugestię opierają na sugerowanej wprost zależności znaczeniowej propozycji Jonatana od analogicznej terminologicznie formuły z Pnp 7,12: lekâ dôdî nẹsēe haśśádeh „chodź, umiłowany, wyjdźmy w pole”, która komunikuje wolę miłosnego spotkania oblubienicy z umiłowanym. Jak w poprzednich przypadkach, tego typu zestawienie jest nieuprawnione $\mathrm{z}$ uwagi na zupełnie odmienną formę i treść porównywanych biblijnych źródeł. Pieśń nad Pieśniami - jako oda zakochanych opisująca ich uczucia, doświadczenia i pragnienia miłosne - wprost sugeruje intymne i erotyczne tło sekretnego spotkania, które ewidentnie widać w najbliższym kontekście analizowanej formuly:

O jak piękna jesteś, jakże powabna, miłości, pełna rozkoszy! Twa postać smukła jak palma, a piersi twe jak winne grona. Rzekłem: wespnę się na palmę, pochwycę kiść daktyli. Niech piersi twe będą dla mnie jak winne grona, a twój oddech jak zapach jabłek. Twe podniebienie jak wyborne wino, które delikatnie spływa we mnie, rozpływa się na wargach, usy-

65 W Księgach Samuela i Królewskich formuła przysięgi i zaprzysiężenia związana jest zwykle z wojną. Gwarantuje ona oszczędzenie kogoś w bitwie czy po niej, wyraża obietnicę wsparcia w wojennej zawierusze albo ma związek z politycznymi planami przejęcia lub utrzymania władzy królewskiej (1 Sm 19,6; $24,22-23 ; 30,15 ; 2 \mathrm{Sm} \mathrm{19,24;} \mathrm{21,2;} 1 \mathrm{Krl} 1,51 ; 2,8.23)$. Wszystkie te kwestie pojawiają się w przymierzu Jonatana z Dawidem w 1 Sm 20,1-42, odzwierciedlając bliskowschodnie standardy dyplomacji i polityki. Wozniak, „Drei verschiedene literarische Beschreibungen des Bundes”, 213-214.

66 Schroer - Staubli, „Saul, David, and Jonathan”, 29.

67 Formuła lekâ $w^{e} n e \overline{e s} \bar{e}^{\prime}$ haśśádeh jest dość często spotykana w Biblii Hebrajskiej jako idiom wyrażający wyjście na tereny otwarte (np. pole walki, pole uprawne), wolę oddalenia się i pozostania na osobności, a nawet płody rolne (Rdz 24,63;27,3; Pwt 14,22; 28,38; Sdz 9,27.42; 1 Sm 20,35; 2 Sm 11,23; 18,6; 2 Krl 4,39; Jr 6,25; 14,18; Mi 4,10). Na bazie tylko pola semantycznego formuły trudno jest sprecyzować cel i przebieg konkretnego wyjścia, określa go bowiem najbliższy i dalszy kontekst narracyjny. Tak jest też w przypadku Pierwszej Księgi Samuela i Pieśni nad Pieśniami, w których najbliższy kontekst przesądza o daleko odmiennym sensie tej samej formuły hebrajskiej: „chodź, wyjdźmy na pole!”. 


\section{DARIUSZ DZIADOSZ}

piając mnie. Ja należę do mego umiłowanego i do mnie zwraca się jego pożądanie. Chodź, umiłowany, wyjdźmy w pole, spędźmy noc w wioskach. Wczesnym rankiem pójdziemy do winnic, by zobaczyć czy kwitnie winorośl, czy pączki się otwarły, czy w kwiatach są już granaty, tam dam ci moje pieszczoty (Pnp 7,7-13).

W tak zdefiniowanym klimacie miłosnej więzi dwojga zakochanych propozycja sekretnego spotkania w polu czy winnicy nabiera automatycznie sensu intymnego (erotycznego, seksualnego), czego autor tej księgi wcale nie ukrywa, opisując drobiazgowo w kolejnych wersach językiem metafory pragnienia i czyny kochanków.

Zupełnie innej wymowy nabiera sens formuły: $l^{e} k a ̂$ we $w^{e} \overline{s ̣}_{\bar{e}}{ }^{\prime}$ haśśādeh (1 Sm 20,11a) w perspektywie sekretnych spotkań Jonatana z Dawidem w sekcji 19,1-21,1. Już wers 19,1 mówi o kolejnym spisku Saula, który wprost namawia Jonatana i swe sługi do zabójstwa Dawida. W konsekwencji Jonatan od razu powiadamia Dawida o realnym zagrożeniu, zalecając mu daleko idącą ostrożność i czasowe ukrycie się $(19,2)$. W świetle tej informacji po raz pierwszy pojawia się motyw pola $(19,3)$. Jonatan mówi o polu, na którym w tym samym czasie będzie w ukryciu przebywał Dawid, a on poprowadzi pertraktacje z zagniewanym ojcem: wa' ănî 'êșé $\bar{e}^{e^{e}} \bar{a} m a d t \hat{\imath}$ lejad-'ābî baśśädeh 'ăšer 'attāh šām „,w międzyczasie ja wyjdę, by stanąć przy mym ojcu na polu, na którym ty sam będziesz". Ten sam wątek ukrycia się w polu porusza Dawid podczas jednej z czterech konwersacji, jakie odbywa z Jonatanem w okresie intryg Saula. Sugerując Jonatanowi w 20,5 skuteczny sposób odkrycia prawdziwych zamiarów króla, prosi go o zgodę na odejście i ukrycie się w polu: wešillahtanî wenistartî baśśādeh „ale pozwól mi, bym odszedł i ukrył się w polu”. Idea wyjścia w pole i pobytu tam z Dawidem na osobności, która wypływa od Jonatana w 20,11a, pojawia się w odpowiedzi na tę właśnie sugestię syna Jessego i podyktowana jest potrzebą konspiracji z uwagi na zamysły króla. Temat zagrożenia życia Dawida jest bowiem motywem przewodnim tej części narracji, opowiadającej o jego pobycie na królewskim dworze (por. 19,8-24; 20,24-b34) i treścią dwu kolejnych spotkań z Jonatanem, które mają miejsce na polu (20,1-24a; 20,35-21,1). Biorąc więc pod uwagę bliski kontekst wierszy 20,11.24.35, mówiących o sekretnym pobycie młodzieńców na polu, nie ma wątpliwości, że jego główną przyczyną była obawa przed gniewem króla. Tych tekstów ani formuły lekâ $w^{e} n e \bar{s} e_{\bar{e}}$ haśśádeh nie można interpretować w sensie intymnej schadzki kochanków pragnących nacieszyć się sobą (Pnp 7,12), lecz koniecznych środków ostrożności, które miały uratować życie Dawida ${ }^{68}$. Z uwagi na intrygi króla,

68 W 19,3; 20,5.11.24.35 pole jest ukazane jako miejsce odosobnienia zapewniające dyskrecję tym, którzy pragną omówić sprawy wagi państwowej. Wpierw na polu Jonatan omawia $\mathrm{z}$ Saulem sprawę Dawida $(19,3)$, potem to syn Jessego deklaruje, iż pragnie ukryć się w polu na czas pertraktacji Jonatana $z$ królem $(20,5)$. Podczas tej rozmowy Jonatan sugeruje, aby wyjść w pole, gdzie w zupełnej konspiracji zapewnia przyjaciela o swej lojalności i poparciu, zawiera z nim przymierze pokoju, przysięgając, iż powiadomi go o wyniku rozmów z ojcem $(20,11-23)$. W 20,24 narrator informuje, że Dawid pozostaje w polu, gdzie ukrywa się przed Saulem i czeka na informacje od Jonatana. W ostatniej części sekcji 20,35-21,1 (20,35) 
młodzieńcy nie mieli bowiem możliwości spotkania w miejscu publicznym i musieli szukać odosobnienia.

\subsection{Podtekst obelgi Saula oskarżającej Jonatana w 1 Sm 20,30}

Ostrym słowom, jakie padają z ust Saula pod adresem Jonatana stającego w obronie Dawida, niektórzy nadają ton oskarżenia o homoseksualizm ${ }^{69}$. Oto kluczowa część wypowiedzi króla, która, w ich rozumieniu, nabiera takiego tonu: ben-na'ăwat hammardît hălô' jāda'tî kî-bōhēr 'attāh leben-jišaj lebošt ${ }^{e} k \bar{a} \hat{u}^{e}$ 'bōšet 'erwat 'immekā „synu przewrotnej i zbuntowanej kobiety! Czy ja nie wiem, że wybrałeś sobie ${ }^{70}$ syna Jessego na twą hańbę i hańbę nagości twej matki” (20,30). Według 1 Sm 14,49-50 żoną Saula była Achinoam, córka Achimaasa - matka Jonatana, Jiszwiego, Malkiszuy oraz Merab i Mikal. Z uwagi na brak informacji, które mogłyby potwierdzić jej tak surową ocenę: „przewrotna i zbuntowana kobieta /służąca/71”, należałoby założyć, że te słowa króla były owocem spontanicznego wzburzenia i gniewu. Potępiając bliski związek Jonatana z Dawidem, który Saul oceniał w kategorii niesubordynacji i rebelii wobec siebie i własnego rodu, w przypływie złości uderzył rykoszetem w jego matkę $^{72}$. Więź następcy tronu z Dawidem, którego Saul już na tym etapie narracji oceniał jako groźnego konkurenta do władzy, była w jego opinii powodem wstydu

znów jest mowa o tym, że Jonatan wychodzi na pole (por. 19,11), by na osobności, przez umówiony wcześniej znak, powiadomić Dawida o nieskutecznej interwencji u ojca. We wszystkich tekstach pole jest więc miejscem odosobnienia, które stanowi przestrzeń poufnych rozmów politycznych i osobistych Jonatana z ojcem, a potem dwukrotnie z Dawidem. W każdym przypadku wybór pola na miejsce dialogu był podyktowany względami bezpieczeństwa i realnym zagrożeniem życia Dawida ze strony Saula i jego ludzi. W świetle tego zestawienia formuła: $l^{k} k \hat{a}$ wenẹșè haśśädeh w 1 Sm 20,11a i Pnp 7,12 sugeruje jedynie analogię natury topograficznej, zaś wyklucza podobieństwo kontekstualne i merytoryczne.

69 Schroer - Staubli, „Saul, David, and Jonathan”, 29-31; Römer - Bonjour, L'homosexualité, 76; Naumann, „David und die Liebe”, 61; Nissinen, Homoeroticism in the Biblical World, 55; Ackerman, When Heroes Love, 187-188; Jobling, 1 Samuel, 161.

70 W użytym w 20,30 rdzeniu bḥr niektórzy dopatrują się idei stałej, świadomej i intymnej relacji Jonatana z Dawidem, którą redaktor księgi sugeruje ustami Saula. Nissinen, Homoeroticism in the Biblical World, 55; Jobling, 1 Samuel, 161. Ten często używany w Biblii termin (ponad 160 razy) tylko w dziesięciu przypadkach określa więź międzyludzką (zwykle w kontekście walki zbrojnej, ani razu w sensie relacji intymnej; por. Wj 17,9; 18,25; Joz 8,3; 1 Sm 13,2; 2 Sm 10,9; 15,15), a w zdecydowanej większości kolokacji dotyczy relacji Boga JHWH do Izraela czy konkretnych postaci biblijnych (Pwt 7,6; 14,2; 18,5;

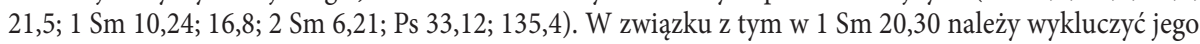
podtekst homoerotyczny. Mówiąc o więzi Jonatana, Saul nie ma na myśli jego uczuciowych czy seksualnych preferencji, lecz społeczno-polityczne konsekwencje jego decyzji. W jego opinii Jonatan, w trudnej dla kraju sytuacji wewnętrznego i zewnętrznego niepokoju, stanął po stronie konkurenta, który występuje przeciw urzędującemu królowi i zagraża stabilności jego dynastii. Bergman - Ringgren - Seebass, „bhr r, 75. Braterstwo młodzieńców w ideowo-teologicznej perspektywie sekcji 1 Sm 16,1 - 2 Sm 7,29 można odczytać też w kluczu historiozbawczym, gdyż jej deuteronomistyczny redaktor kilka razy mówi o Bożym wybraństwie syna Jessego (1 Sm 16,8-10; 2 Sm 6,21). Wybór Jonatana jest w tym świetle uznany za ludzką reminiscencję Bożego wyboru, która zapowiada trwałą zmianę na tronie Izraela.

71 Tsumura, The First Book of Samuel, 519.

72 Klein, 1 Samuel, 208; Himbaza - Schenker - Edart, The Bible, 32-34. 
i hańby ${ }^{73}$. Bliski i dalszy kontekst wiersza 20,30 sugerują, że ocena Saula była uwarunkowana względami społecznymi (różnica pochodzenia i zamożności) i politycznymi (konflikt Beniamina z Judą), które król - dla większego efektu - ubrał w formę przekleństwa i groźby. Według Saula Jonatan, rezygnując z sukcesji tronu na rzecz Dawida, sprowadził na siebie i swój ród hańbę i wstyd ${ }^{74}$, których wymiar król zilustrował eufemistyczną treścią formuły: 'erwat 'immekā „nagość (narządy rodne) twej matki". W jego ustach ten obraz przyjmuje wymiar przekleństwa, ale naciska bardziej na hańbę i wstyd, jakie Jonatan sprowadził na królewski ród i pokolenie Beniamina, niż na narządy rodne królewskiej żony, z których wyszedł ${ }^{75}$. Ekspresja wulgaryzmu ma zdyskredytować Dawida w oczach następcy tronu, tak iż już sama myśl o bliskiej z nim więzi winna go wprowadzać w stan zakłopotania porównywalny z sytuacją, w której musiałby oglądać narządy rodne matki. Paktując z wrogiem ojca i własnego rodu, stanie się bowiem kiedyś, razem ze swoją matką, podwładnym Dawida, zamiast jego panem i władcą, do czego jest przeznaczony jako prawowity sukcesor tronu.

A zatem i słowa przekleństwa Saula mają wyraźną podbudowę ideowo-polityczną, a nie etyczno-moralną, na którą pozornie mogłyby wskazywać terminy: 'erwat „nagość (narządy rodne)” i bōšet „wstyd, hańba” (20,30). Gdyby Saul w tym momencie miał na myśli postawę homoseksualną syna, przekleństwo odniósłby do niego, a nie jego matki ('erwat' immekā). Na bazie słów króla z 20,30 jedynej aluzji do niemoralności można byłoby upatrywać w relacji do jego żony ${ }^{76}$, ale ta nie podlega weryfikacji z uwagi na brak informacji źródłowych w tej materii.

\subsection{Pole semantyczne rdzenia nšq w $1 \mathrm{Sm} 20,41$}

Niewłaściwie użyta metoda intertekstualnej lektury Biblii prowadzi też do konfrontacji tekstów Pierwszej Księgi Samuela z Pieśnią nad Pieśniami pod kątem czasownika $n \bar{a} s ̌ a q^{77}$. Rdzeń nšq pojawia się 32 razy w Biblii Hebrajskiej, a jego sens zależy od koniugacji, w której występuje: w qal oznacza „całować, dotykać”, w piel „całować długo, namiętnie”, zaś w hifil „dotykać się wzajemnie”. Rzeczownik $n^{e}$ šì qāh „pocałunek" występuje w Biblii Hebrajskiej tylko 12 razy $^{78}$, wyrażając przywiązanie, uczucia

73 Pojęcie bōšet „wstyd, hańba” w Biblii Hebrajskiej wraca trzydziestokrotnie, ale tylko raz sugeruje kontekst aktu seksualnego, i to w sensie teologicznej symboliki (idolatria Izraela w Oz 9,10). Nel, „bwš”, 626.

74 McCarter, 1 Samuel, 343.

75 Niektórzy sugerują, że Saul obwinia syna o zdradę stanu, która okrywa hańbą i wstydem nie tylko jego samego, ale i cały królewski ród, symbolizowany tu przez matkę Achinoam. Bergen, 1, 2 Samuel, 217; Gagnon, The Bible and Homosexual Practice, 150.

76 W opinii niektórych przekleństwo i obelga pod adresem matki Jonatana są sugestią jego nieprawego pochodzenia, które sugeruje Saul (i jego bliskie otoczenie) na widok przymierza zawartego z politycznym wrogiem urzędującego monarchy Izraela. Smith, A Critical and Exegetical Commentary, 193.

77 Schroer - Staubli, „Saul, David, and Jonathan”, 29.

78 Beyse, „nāšaq", 73-74. 
i emocje w obrębie: miłości (Pnp 1,2; 8,1; Prz 7,13)79, pokrewieństwa (Rdz 27,26-27; $29,11 ; 31,28 ; 32,1 ; 33,4 ; 45,15 ; 48,10 ; 50,1 ;$ Rt $1,9.14 ; 1 \mathrm{Krl} 19,20)^{80}$ i przyjaźni. W ten ostatni krąg zażyłych ludzkich więzi manifestowanych pocałunkiem (objęciem się) Księgi Samuelowe wpisują nie tylko braterską relację Jonatana i Dawida (1 Sm 20,41), ale też Samuela i Saula (1 Sm 10,1), Dawida i Barzillaja (2 Sm 19,40), Absaloma i jego zwolenników spiskujących przeciw Dawidowi (2 Sm 15,5). Do tych tradycji można zaliczyć też opis podstępnej postawy Joaba, który pocałunkiem udaje przyjaźn do Amasy, by go zabić (2 Sm 20,9). Jak widać, pocałunek w Księgach Samuela, bardziej niż osobiste więzy uczuciowe i emocjonalne, symbolizuje i manifestuje trwałą wspólnotę interesów społeczno-politycznych i militarnych, stając się oznaką ludzkiej wierności, lojalności, solidarności czy przebaczenia ${ }^{81}$.

$\mathrm{Na}$ bazie analizy strategii narracyjnej w $18,1-21,1$ pocałunku Jonatana i Dawida z 20,41 w żaden sposób nie można odnieść do intymnego klimatu miłosnej relacji oblubieńców, o której mówi Pieśń nad Pieśniami w 1,2 i 8,1. Najbliższy kontekst dla 20,41, czyli perykopa 20,35-21,1 relacjonująca sekretne spotkanie na polu (por. 20,$35 ; 21,1$ ), rozgrywa się w atmosferze realnego zagrożenia życia Dawida ze strony Saula. Po nieudanej próbie mediacji $(20,24-34)$ Jonatan w umówiony wcześniej sposób i przy zachowaniu nadzwyczajnych środków ostrożności (20,5-10.18-22) ostrzega przyjaciela (20,35-40), a potem w emocjonalny sposób (pocałunek i płacz) się z nim żegna $(20,41)$, odwołując się do obowiązującego ich religijno-politycznego przymierza $(20,42)$. Sens frazy wajjišš $q \hat{u}$ ' 'ǐ̌s 'et-rēe ēh $\hat{u}$ „ucałowali się (objęli jeden drugiego)" w tych wyjątkowych okolicznościach nie sugeruje tła intymności i seksualnej bliskości, lecz wyraża dramaturgię zaistniałej sytuacji, która sprzyja manifestacji głębokich uczuć, takich jak: braterska miłość, współczucie, troska i solidarność, a także przywołuje klimat dwustronnego przymierza, jakie zawarli obaj młodzieńcy. W świetle wzajemnych deklaracji pokoju i ugody, wypowiedzianych w atmosferze walki o tron (20,12-17.23.42), rzewne pożegnanie zaprzyjaźnionych kandydatów do władzy ma także podłoże polityczne, w którym pocałunek jest oznaką i dowodem ludzkiej i Bożej życzliwości (por. 10,1). Na taką lekturę zdarzeń wskazuje też fakt uczuciowych więzów wynikających z powinowactwa Dawida z Jonatanem, jakie zrodziły się od małżeństwa z Mikal (18,27-28). I one, zgodnie z religijno-kulturowym

79 Czasownik nāšaq jest stosunkowo rzadką formą obrazowania uczuć w obrębie relacji małżeńskich, narzeczeńskich czy innych więzi uczuciowych mężczyzny z kobietą. Zwykle pojawia się on w okolicznościach zdobycia sławy, władzy czy szacunku (1 Sm 10,1), powitania po długiej rozłące (Rdz 33,4; 45,15; Wj 4,27; 2 Sm 14,33-34) czy też pożegnania (Rdz 31,28; 32,1; Rt 1,9.14; 1 Krl 19,20).

80 Więzy rodzinne i klanowe to najczęstsza w Biblii Hebrajskiej przestrzeń, w której pocałunkiem wyraża się: miłość, braterstwo, wierność, lojalność, błogosławieństwo i solidarność (Rdz 27,26-27; 29,13; 31,28; 32,1;

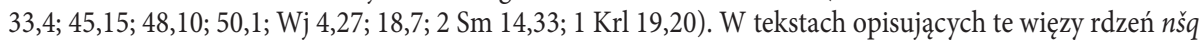
odnosi się najczęściej do pocałunku spokrewnionych lub spowinowaconych ze sobą mężczyzn (wyjątek to Noemi, Rut i Orfa w Rt 1,9.14), ale nigdy nie komunikuje podłoża erotycznego czy seksualnego. 
kodem Biblii, nie pozwalają nadać emocjonalnemu pożegnaniu, opisanemu w 20,41, znamion gestu erotycznego.

Od wszystkich tych tradycji znaczeniowo odbiega natomiast Pieśń nad Pieśniami, która stosuje ten sam hebrajski czasownik: jiššāqēnî minnešsi qôt pihû kî-tôbîm dōdệkā mijjājin „,niech mnie całuje pocałunkami swych ust, gdyż twa miłość jest lepsza od wina" $(1,2)^{82}$. Jest to jedna z zaledwie dwu kolokacji biblijnych (por. Prz 7,13), w których rdzeń nšq wskazuje wprost na erotyczny koloryt więzi mężczyzny z kobietą. W żadnej z tych kolokacji nie odnosi się on do relacji homoseksualnej, co kolejny raz podważa zasadność metodologii, która bezpodstawnie łączy takie teksty, jak na przykład: 1 Sm 20,41 i Pnp 1,2, by na bazie tylko pokrewieństwa terminologii sugerować ich tematyczną zbieżność lub zależność. Tymczasem pocałunek (objęcia) i płacz ${ }^{83}$ młodzieńców w 1 Sm 20,41 trzeba tłumaczyć względami braterskiej przyjaźni i pokrewieństwa (powinowactwa) klanowego, jak również wymogami dworskiej etykiety, która obowiązywała krewnych monarchy i partnerów społeczno-politycznego przymierza. Pierwsze dwa względy nie wymagają szerszego komentarza, na trzeci jasne światło rzuca tekst 1 Sm 10,1 mówiący o pocałunku Samuela, którym prorok obdarzył namaszczonego na wodza (nāgîd) Izraela - Saula, informując go o Bożym wybraństwie, realnym wsparciu (duch JHWH) oraz społeczno-politycznej i militarnej misji do spełnienia (10,1-8). Rytualny pocałunek w tej sytuacji był uważany za oznakę społeczno-religijnej aprobaty dla Saula ze strony najwyższego lokalnego autorytetu. W analogicznej perspektywie należy patrzeć na gest Jonatana, który jako prawowity spadkobierca urzędu Saula i politycznych aspiracji rodu Beniamina, po ogłoszeniu własnej abdykacji i poparcia dla Dawida (20,13-17), pocałunkiem potwierdza aprobatę dla jego starań o władzę w państwie. Wiążąc ten gest z postawą Samuela wobec Saula $(10,1)$, już na tym etapie narracji można przypuszczać, że rezygnacja Jonatana z władzy jest nieodwołalna, a jej przejęcia dokona syn Jessego i ród Judy. Tę interpretację potwierdza najbliższy kontekst (20,35-21,1), który tworzy klimat konspiracji wywołany groźbami króla, a zarazem wprowadza temat wdzięczności Dawida za braterską i polityczną lojalność Jonatana ${ }^{84}$. Pełne emocji i uczuć po-

82 Pieśń nad Pieśniami odwołuje się do czasownika nāšaq również w 8,1. Choć najbliższy kontekst pieśni $(6,11-8,4)$ to nadal intymny dialog zakochanych, który przywołuje ich miłosne (erotyczne) wyznania i doznania, pocałunek w 8,1 komunikuje wyjątkowo ideę intymności bratersko-siostrzanej: „o gdybyś był moim bratem, który ssał pierś mej matki, spotkawszy cię na zewnątrz, ucałowałabym cię nie narażając się na pogardę innych".

83 Wiersz $1 \mathrm{Sm}$ 20,41b mówi o silnych męskich emocjach wyrażanych płaczem: wajjibkû 'îs 'et-rē'ēhù 'ad-dāwid higdîl „płakali razem (jeden nad drugim) aż Dawid się wzmocnił”.

84 Zakres i intensywność tej wdzięczności Dawid ilustruje zewnętrznym gestem, którym wita przyjaciela:

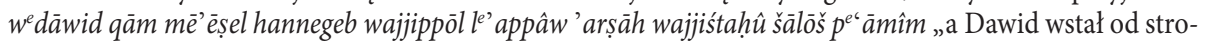
ny południa, upadł twarzą na ziemię i oddał trzy razy pokłon” (20,41a). Dopiero w następstwie tego gestu rewerencji ma miejsce scena pożegnania, w której silne emocje młodzieńcy wyrażają pocałunkiem (objęciem) i płaczem. Ta scena sugeruje równość społeczną między nimi, choć na tym etapie narracji to wciąż Jonatan jest oficjalnym pretendentem do tronu. Zehnder, „Observations on the Relationship”, 149-150. 
żegnanie $(20,41)$ jest ilustracją głębokiego braterstwa młodzieńców, a jednocześnie wyrazem ich niepewności wobec najbliższej przyszłości. Obaj są świadomi, że może to być ich ostatnie spotkanie (por. 23,16-18) z uwagi na rosnący chaos wewnętrzny (walka o tron) i zewnętrzny (Filistyni) w państwie. Jego spontaniczny charakter dyktowały więc zrozumiałe okoliczności przymusowego rozstania, a zarazem względy przyjacielskiej ugody, gwarantującej wzajemną wierność i życzliwość na daleką przyszłość. Jednym słowem, termin nāšaq w 20,41 nie ma podtekstu intymności (homoseksualnego erotyzmu), lecz jest symbolem autentycznego żywego braterstwa młodzieńców, które zdominował smutek i przygnębienie z powodu rozłąki ${ }^{85}$.

\subsection{Pole semantyczne określeń: nā'îm (2 Sm 1,23.26) i ’āh (2 Sm 1,26)}

Komentatorzy, którzy sugerują homoseksualną relację Dawida z Jonatanem, dopatrują się jej intymnego podtekstu nawet w tytułach: $n \bar{a}^{\prime} \hat{\imath} m$,ulubiony, pełen uroku,

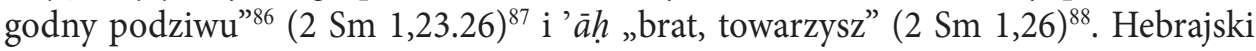
rdzeń $n^{6} m$ wpisuje się istotnie w bogaty biblijny język miłości, ale demonstruje różne aspekty znaczeniowe, które determinuje każdorazowo konkretny kontekst narracyjny. Termin $n \bar{a}^{`} \hat{\imath} m \mathrm{w}$ żałobnej pieśni Dawida $(1,23.26)$ na pewno wyraża jego bliską uczuciowo-emocjonalną więź z poległym Jonatanem, jednak bez podłoża erotycznego. W tym samym żałobnym utworze termin ten dotyczy bowiem na równi też nieżyjącego Saula (1,23): šă' ûl wîhônātān hanne’ ĕhābîm wehann"`îmîm "Saul i Jonatan, umiłowani i pełni wdzięku". Odniesienie przez Dawida tego samego pojęcia $n \bar{a}^{`} \hat{i} m$ do króla i jego syna w zasadzie wyklucza jego homoerotyczny (seksualny) podtekst w tym konkretnym kontekście, co nie oznacza, że takiego wydźwięku nie nabiera ono w innych tekstach biblijnych, np. w Pieśni nad Pieśniami ${ }^{89}$. W nasyconych intymnością i erotyką wyznaniach obojga kochanków przymiotnik $n \bar{a}^{‘} i ̂ m$ sugeruje wprost seksualny i cielesny wymiar ludzkiego piękna i wdzięku: hinnāk jāpāh ra'jātî̀ hinnāk jāpāh 'ênajik jônim hinnekā jāpeh dôdî' ap nā'îm 'ap-'ărśênû ra'ănānāh

85 Tak tę scenę odczytał m.in. Rembrandt. Na płótnie Dawid i Jonatan z 1642 r. syn Saula ma twarz malarza, na której widać wielki smutek, tęsknotę i cierpienie z powodu rozstania. Mistrz namalował ten obraz po śmierci ukochanej żony, chcąc wyrazić intensywność bólu rozłąki. Burnet, „Rembrandt”, 11-12.

86 Schroer - Staubli, „Saul, David, and Jonathan”, 30.

87 Rdzeń $n^{6} m$ występuje w Biblii Hebrajskiej przede wszystkim w poezji i literaturze mądrościowej. W formie czasownikowej $n \bar{a}^{‘} a m$ „być umiłowanym, drogim, podobać się, być godnym miłości i upodobania, znaleźć upodobanie, pragnąć" pojawia się osiem razy, w formie przymiotnikowej nā'îm „ulubiony, godny podziwu, pełen uroku” trzynaście razy, a w formie rzeczownikowej nō'am „powab, wdzięk, miłe usposobienie, łagodność, grzeczność, przyjemność" siedem razy. Kronholm, "nā‘am”, 468-472.

88 Keel, Das Hohelied, 152-153; Schroer - Staubli, „Saul, David, and Jonathan”, 30.

89 Rdzeń $n^{6} m$ pojawia się w księdze jedynie dwa razy $(1,16 ; 7,7)$, co sugeruje, że nie należy on do wiodącej terminologii Pieśni nad Pieśniami. Nie ma też żadnego poważnego argumentu, by jego intymny sens wynikający z literackiego kontekstu (język miłosnej intymności i erotyzmu) przykładać do tradycji historycznych o dojściu Dawida do władzy w Izraelu (1 Sm 16,1 - 2 Sm 5,5), nawet gdy występuje w passusie poetyckim (2 Sm 1,19-27). 
„o jak jesteś piękna, moja przyjaciółko, o jak piękna, twe oczy są gołębicami! O jak piękny jesteś, umiłowany mój, o jak powabny (pełen uroku)! Nasze łoże jest jak zielona trawa (pełne rozkoszy)" (1,15-16; por. 7,7-10). Passusy te są jednak jedynymi tekstami w Biblii, w których rdzeń $n^{6} m$ ma tak oczywiste zabarwienie erotyczne (heteroseksualne).

Forma literacka zaprezentowanej publicznie pieśni Dawida, adresowanej na równi do Saula i Jonatana, oraz jej wyraźnie zdefiniowany bliski i dalszy kontekst (społeczno-polityczna walka o tron w Izraelu) wyklucza więc homoerotyczny podtekst $n^{\text {‘ }} \mathrm{m}$ nie tylko w 2 Sm 1,23, ale i w 1,26. W nasyconym smutkiem i żałobą wyznaniu: șar-lî

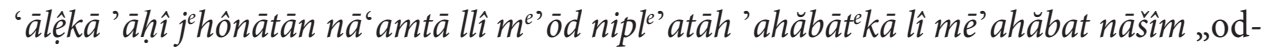
czuwam żal po tobie, mój bracie Jonatanie. Byłeś mi bardzo drogi. Twa miłość była dla mnie bardziej cudowna /cenna/ niż miłość kobiet" - zgodnie z ideowo-teologicznym profilem księgi - należy szukać śladów niezwykle bliskiej, a nawet intymnej więzi, ale bez wprost sugerowanego podtekstu homoerotycznego. Czasownik nāa am „polubić, podziwiać, mieć upodobanie” i rzeczownik 'ahăbāh „miłość, upodobanie”, w klimacie pieśni, nabierają sensu osobowego braterstwa i partnerstwa społeczno-politycznego.

Tonu homoseksualnej intymności nie należy też dopatrywać się w polu semantycznym pojęcia 'āh „brat, towarzysz” w 1,26, co bezpodstawnie czynią ci, którzy konfrontują ten termin z treścią Pnp 8,1. Nie bacząc na wyraźnie zdefiniowany w Pnp 8,1 sens pojęcia 'ạh - w tym wierszu wyjątkowo nie oznacza ono kochanka, oblubieńca, ale rodzonego brata - sugerując się ogólnym profilem księgi ${ }^{90}$, przypisują mu podtekst intymny, a następnie, wbrew standardom metodologii biblijnej, odnoszą wprost do $2 \mathrm{Sm} \mathrm{1,26.} \mathrm{Tymczasem} \mathrm{w} \mathrm{tradycjach} \mathrm{biblijnych} \mathrm{(Rdz} \mathrm{24,27;}$ Sdz 20,23.28; 1 Sm 30,23; 2 Sm 19,13; 1 Krl 9,13; 20,32-34; 2 Krl 10,13; Jr 22,18) oraz w literaturze i dyplomacji królewskiej starożytnego Bliskiego Wschodu ${ }^{91}$ tytuł „brat, towarzysz" jest często używaną definicją partnera w procesie stypulacji świeckich i religijnych przymierzy i umów, a także pełnym szacunku określeniem sojusznika czy sąsiada (1 Sm 25,6; 2 Sm 20,9 $)^{92}$. W tym miejscu trzeba raz jeszcze przywołać

90 Wbrew najbliższemu kontekstowi pieśni (8,1-2), niektórzy przypisują pojęciu 'āh sens: „kochanek” na zasadzie analogii do tytułu 'ăhōtî „moja siostra”, który w ustach bohatera księgi określa jego kallâ „oblubienicę" (Pnp 4,9.10.12; 5,1.2). Ackerman, When Heroes Love, 191; Römer - Bonjour, L'homosexualité, 99; Zehnder, „Observations on the Relationship”, 152; Comstock, Gay Theology, 88. Trzeba też pamiętać, że Biblia Hebrajska, mówiąc o kochankach, ma zawsze na myśli pary heteroseksualne.

91 Przykładem może być tekst umowy hetyckiego króla Suppiluliumą I z Hukkanasem - przywódcą ludu Hajasa-Azzi zamieszkującym tereny dzisiejszej Armenii i Turcji z końca II tysiąclecia przed Chr.. Kitchen - Lawrence, Treaty, Law and Covenant, 441 (tekst nr 60.3,12-13). Tytuł „brat” na określenie partnera przymierza pojawia się też w dokumencie z 1258 r. przed Chr., potwierdzającym ugodę między królem Egiptu Ramsesem II a hetyckim władcą Hattusilisem (ANET, 201-203). Pritchard, Ancient Near Eastern Texts, 201-203.

92 Język braterstwa i ojcostwa oraz idea męskiej miłości, lojalności, wierności i przymierza są typowe nie tylko dla epoki monarchii, ale i dużo wcześniejszych pokoleniowych (klanowych) struktur Izraela. Relację Dawida do Jonatana należy odczytać w tym właśnie duchu. Cross, From Epic to Canon, 11; McCarter, 2 Samuel, 77. 
relację powinowactwa, w którą obaj mężczyźni weszli po ślubie syna Jessego z Mikal (1 Sm 18,27-28). W myśl biblijnych standardów, na mocy tego faktu stali się braćmi (por. Rt 4,3). Na koniec warto przypomnieć, że żaden z kontekstów Biblii Hebrajskiej odwołujących się do 'ạh nie sugeruje podtekstu erotycznego (seksualnego), stąd i w 2 Sm 1,26 trudno jest doszukiwać się tego rodzaju pola semantycznego.

\section{Podsumowanie}

Pochodzące z różnych środowisk i epok pisarskich tradycje staro- i nowotestamentowe w kwestii czynów homoseksualnych są spójne i jednomyślne. W ich ocenie tego typu związki noszą piętno moralnej winy i deformują wolę Stwórcy, który międzyludzkie relacje oparł od początku na bliskiej więzi mężczyzny i kobiety w ramach instytucji małżeństwa (Rdz 1,26-28; 2,18-25). Synagoga żydowska i Kościól, jako spadkobiercy tych starożytnych tekstów, stają nieprzerwanie przed trudnym wyzwaniem, by odważnie przywoływać te zasady biblijnej antropologii. W aktualnym klimacie nieograniczonej tolerancji i światopoglądowej wolności to zadanie staje się coraz trudniejsze. Wypływająca z Biblii ocena homoseksualizmu w kategorii grzechu i nieporządku moralnego jest powszechnie odrzucana przez współczesne prądy ideowo-kulturowe jako znak homofobii i nietolerancji. Jednocześnie dyskusję na temat praw i przywilejów dla osób homoseksualnych przenosi się na płaszczyznę doktrynalną, w tym na platformę studiów biblijnych. Konkretnym dowodem tego fenomenu jest obecna w różnych środowiskach społecznych i ośrodkach uniwersyteckich lektura niektórych tradycji Biblii w duchu idei homoseksualizmu, wśród których zdecydowany prym wiedzie przekaz o Dawidzie i Jonatanie.

Analiza literacka i egzegetyczno-teologiczna 1 Sm 18,1 - 2 Sm 1,27 dowodzi jednak, że ten materiał źródłowy nie ma zamierzonego przez redaktorów podtekstu homoerotycznego czy homoseksualnego, jak sugerują niektórzy komentatorzy. Kolejne odsłony tej sekcji nie dają podstaw, by więź tych mężczyzn interpretować w kategorii relacji intymnej. Redaktorzy sekcji 18,1-21,1; 23,16-18; 2 Sm 1,19-27 nie stosują żadnych terminów czy idei, których Biblia Hebrajska używa na określenie praktyk homoseksualnych. Teksty te nie wykazują też kontekstualnej czy merytorycznej zależności od Pieśni nad Pieśniami. Obecność tych samych lub podobnych terminów w Pierwszej Księdze Samuela i w Pieśni nad Pieśniami ma charakter ograniczony i nie wpływa na interpretację diametralnie odmiennych przesłań społeczno-kulturowych i teologicznych komunikowanych w tych księgach. Pojęcia, które w Pieśni nad Pieśniami mają koloryt wybitnie intymny (erotyczny) z uwagi na jej specyficzną formę literacką (pieśń miłosna weselna), nie mogą być w tym samym sensie odniesione do społeczno-politycznego i militarnego klimatu tradycji o dojściu Dawida do 
władzy (1 Sm 16,1 - 2 Sm 5,5), gdyż wypaczyłyby intencje ich autorów i redaktorów. Ponadto ani w Pieśni nad Pieśniami, ani w Pierwszej Księdze Samuela nie występują terminy, które w jakikolwiek sposób sugerowałyby postawę lub orientację homoseksualną. Co więcej, biblijna rekonstrukcja przyjaźni Dawida z Jonatanem nie zawiera pojęć, które podpowiadałyby jej ton intymny (seksualny, erotyczny). Rekonstrukcja braterstwa Dawida i Jonatana jest integralną częścią źródłowego opisu społeczno-politycznych transformacji w Izraelu w epoce rodzącej się monarchii, zbudowaną według norm teologicznej (historiozbawczej) historiografii biblijnej. Więź Jonatana i Dawida ma więc wymiar aseksualny. Biblia Hebrajska potrafi bowiem mówić o czystej i pięknej przyjaźni mężczyzn i kobiet nawet przy użyciu terminologii i kontekstów, których zwykle używa do opisania heteroseksualnych relacji intymnych.

\section{Bibliografia}

Ackerman, S., „The Personal Is Political: Covenantal and Affectionate Love ('Ahēb, 'Ahăbâ) in the Hebrew Bible", Vetus Testamentum 52/4 (2002) 437-458.

Ackerman, S., When Heroes Love. The Ambiguity of Eros in the Stories of Gilgamesh and David (New York: Columbia University Press 2005).

Ackroyd, P.R., „The Verb Love ('āhēè) in the David - Jonathan Narratives. A Footnote”, Vetus Testamentum 25 (1975) 213-214.

Amzallag, N. - Avriel, M., „Complex Antiphony in David's Lament and Its Literary Significance", Vetus Testamentum 60/1 (2010) 1-14.

Anderson, A.A., 2 Samuel (Word Biblical Commentary 11; Dallas, TX: Word Books 1989).

Arnold, B.T., „The Love-Fear Antinomy in Deuteronomy 5-11”, Vetus Testamentum 61/4 (2011) 551-569.

Balch, D., Homosexuality, Science, and the "Plain Sense" of Scripture (Grand Rapids, MI: Eerdmans 2000).

Baumgart, N., „Saul und David Schlagen - Israels Frauen aus den Städten singen”, Verborgen lezers (red. A. van Wieringen) (Theologische Perspectieven. Supplement Series 2; Bergambacht: Uitgeverij 2011) 3-32.

Bergen, R.D., 1, 2 Samuel (The New American Commentary 7; Nashville, TN: Broadman \& Holman 1996).

Bergman, J. - Haldar, A. - Wallis, G., „'āhab”, Theological Dictionary of the Old Testament (red. J. Botterweck - H. Ringgren) (Grand Rapids, MI: Eerdmans 1990) I, 99-117.

Bergman, J. - Ringgren, H. - Seebass, H., „bhr”, Theological Dictionary of the Old Testament (red. J. Botterweck - H. Ringgren) (Grand Rapids, MI: Eerdmans 1990) II, 73-87.

Beyse, K., ,nāšaq", Theological Dictionary of the Old Testament (red. J. Botterweck - H. Ringgren - H. Fabry) (Grand Rapids, MI: Eerdmans 1999) X, 72-76.

Botterweck, J., "hāpēș", Theological Dictionary of the Old Testament (red. J. Botterweck H. Ringgren) (Grand Rapids, MI: Eerdmans 1990) V, 92-107. 
Brawley, R.L., Biblical Ethics and Homosexuality. Listening to Scripture (Louisville, KY: Westminster John Knox Press 1996).

Brueggemann, W., „Narrative Coherence and Theological Intentionality in 1 Samuel 18”, Catholic Biblical Quarterly 55/2 (1993) 225-243.

Burnet, R., „Rembrandt and the Iconography of David and Jonathan”, Die Bibel in der Kunst 2 (2018) 1-14.

Comstock, G.D., Gay Theology Without Apology (Cleveland, OH: Pilgrim Press 1993).

Countryman, L.W., „Homosexuality”, Eerdmans Dictionary of the Bible (red. D.N. Freedman) (Grand Rapids, MI: Eerdmans 2000) 602-603.

Cross, F.M., From Epic to Canon. History and Literature in Ancient Israel (Baltimore, MD: John Hopkins University Press 1998).

Davidson, R.M., Flame of Yahweh. Sexuality in the Old Testament (Peabody, MA: Hendrickson 2007).

De Young, J.B., Homosexuality. Contemporary Claims Examined in Light of the Bible and Other Ancient Literature and Law (Grand Rapids, MI: Kregel 2000).

Dietrich, W., The Early Monarchy in Israel. The Tenth Century B.C.E. (Biblical Encyclopedia 3; Atlanta: Society of Biblical Literature 2007).

Dietrich, W., „Doch ein Text hinter den Texten? Vorläufige textkritische Einsichten eines Samuelkommentators", Archaeology of the Books of Samuel. The Entangling of the Textual and Literary History (red. P. Hugo - A. Schenker) (Supplements to Vetus Testamentum 132; Leiden: Brill 2010) 133-159.

Dietrich, W., „Stefan Heyms Ethan ben Hoshaja und der Hauptverfasser der Samuelbücher”, The Books of Samuel. Stories - History - Reception History (red. W. Dietrich) (Leuven: Peeters 2016) 3-40.

Fleming, E., „Political Favoritism in Saul's Court: נעם , נפיץ, and the Relation between David and Jonathan", Journal of Biblical Literature 135/1 (2016) 19-34.

Furnish, V., „Homoseksualizm”, Encyklopedia biblijna (red. P.J. Achtemeier) (Prymasowska Seria Biblijna; Warszawa: Vocatio 1999) 398-399.

Gagnon, R.A.J., The Bible and Homosexual Practice. Texts and Hermeneutics (Nashville, TN: Abingdon Press 2001).

Gerig, B.L., „Jonathan and David: Their Three Covenants. Homosexuality and the Bible” (2006), http://epistle.us/hbarticles/jondave6.html [dostęp: 11.01.2020].

Gerig, B., „Jonathan and David: The Debate Continues. Homosexuality and the Bible” (2009), http://epistle.us/hbarticles/jondave11.html [dostęp: 11.01.2020].

Gerig, B.L., Jonathan and David. A Love Story. A Survey of Commentary Interpretation. Textual Evidence, and Historical Background (2012), http://epistle.us/hbarticles/jondavealovestory.pdf [dostęp: 14.05.2020].

Goss, R.E. - West, M., Take Back the Word. A Queer Reading of the Bible (Cleveland, OH: Pilgrim Press 2000).

Gunn, D.M., The Fate of King Saul (Journal for the Study of the Old Testament Supplement Series 14; Sheffield: JSOT Press 1980).

Haag, H. - Ellinger, K., „Stört nicht die Liebe”. Die Diskriminierung der Sexualität - ein Verrat an der Bibel (Olten: Walter 1986). 


\section{DARIUSZ DZIADOSZ}

Hammaren, N. - Johansson, T., „Homosociality: In Between Power and Intimacy”, Sage Journals Open 4/1 (2014) 1-11.

Harding, J., „Opposite Sex Marriage a Biblical Ideal? The Case of David and Jonathan”, Pieces of Ease and Grace. Biblical Essays on Sexuality and Welcome (red. A.H. Cadwallader) (Adelaide: AFT Theology 2013) 35-52.

Harding, J., The Love of David and Jonathan. Ideology, Text, Reception (Dunedin: Routledge 2016).

Heacock, A., Jonathan Loved David. Manly Love in the Hebrew Bible and the Hermeneutics of Sex (Sheffield: Phoenix Press 2011).

Hentschel, G., 2 Samuel (Würzburg: Echter 1994).

Himbaza, I. - Schenker, A. - Edart, J.-B., The Bible on the Question of Homosexuality (Washington, D.C.: Catholic University of America Press 2012).

Horner, T., Jonathan Loved David. Homosexuality in Biblical Times (Philadelphia, PA: Westminster 1978).

von der Horst, D., Jonathan's Loves, David's Laments. Gay Theology, Musical Desires, and Historical Difference (Eugene, OR: Pickwick 2017).

Hügel, K., Homoerotik und Hebräische Bibel (Hamburg: Diplomica 2009).

Jobling, D., 1 Samuel (Berit Olam; Collegeville: Liturgical Press 1998).

Johnson, B.J.M., Reading David and Goliath in Greek and Hebrew. A Literary Approach (Forschungen zum Alten Testament 2/82; Tübingen: Mohr Siebeck 2015).

Kaiser, O., „David und Jonathan. Tradition, Redaktion, und Geschichte in 1 Sam 16-20. Ein Versuch", Ephemerides Theologicae Lovanienses 66 (1990) 281-296.

Keel, O., Das Hohelied (Zürcher Bibelkommentare. AT 18; Zürich: Theologischer Verlag 1986).

Kitchen, K.A., - Lawrence, P., Treaty, Law and Covenant in the Ancient Near East. I. The Texts (Wiesbaden: Harrassowitz 2012).

Klein, R.W., 1 Samuel (World Biblical Commentary 10; Dallas, TX: Word Books 1983).

Kottsieper, I., „šāba “” Theological Dictionary of the Old Testament (red. J. Botterweck - H. Ringgren - H. Fabry) (Grand Rapids, MI: Eerdmans 2004) XIV, 311-335.

Köstenberger, A.J. - Jones, D.W., God, Marriage, and Family. Rebuilding the Biblical Foundation (Wheaton, IL: Crossway 2010).

Krondorfer, B., „Who's Afraid of Gay Theology? Men's Studies, Gay Scholars, and Heterosexual Silence", Theology and Sexuality 13/3 (2007) 257-274.

Kronholm, T., „nā'am”, Theological Dictionary of the Old Testament (red. J. Botterweck H. Ringgren - H. Fabry) (Grand Rapids, MI: Eerdmans 1998) IX, 467-474.

Launderville, D., Celibacy in the Ancient World. Its Ideal and Practice in Pre-Hellenistic Israel, Mesopotamia, and Greece (Collegeville, MN: Liturgical Press 2010).

Lawton, R.B., „Saul, Jonathan, and the 'son of Jesse”, Journal for the Study of the Old Testament 58 (1993) 35-46.

Lemański, J., Księga Rodzaju. Rozdziały 11,27-36,43. Wstęp, przekład z oryginału, komentarz (Nowy Komentarz Biblijny. Stary Testament 1/2; Częstochowa: Edycja Świętego Pawła 2014).

Linafelt, T., „Private Poetry and Public Eloquence in 2 Samuel 1:17-27. Hearing and Overhearing David's Lament for Jonathan and Saul', The Journal of Religion 88 (2008) 497-526.

McCarter, P., 1 Samuel (New Haven, CT: Doubleday 1980). 
McCarter, P., 2 Samuel (New Haven, CT: Doubleday 1984).

McKenzie, S.L., King David. A Biography (Oxford: Oxford University Press 2000).

Michael, M., „Anger Management and Biblical Characters. A Study of «Angry Exchange» among Characters of Hebrew Narrative", Old Testament Essays 28/2 (2015) 451-480.

Moran, W.L., „Ancient Near Eastern Background of the Love of God in Deuteronomy”, Catholic Biblical Quarterly 25/1 (1963) 77-87.

Nardelli, J.-F., Homosexuality and Liminality in the Gilgamesh and Samuel (Classical and Byzantine Monographs 64; Amsterdam: Hakkert 2007).

Naumann, T., „David und die Liebe”, König David - biblische Schlüsselfigur und europäische Leitgestalt (red. W. Dietrich - H. Herkommer) (Freiburg: Universitätsverlag 2003) 51-83.

Nel, P., „bwš”, New International Dictionary of the Old Testament and Exegesis (red. W. VanGemeren) (Grand Rapids, MI: Zondervan 1997) I, 621-627.

Nihan, C. - Nocquet, D., „1-2 Samuel”, Introduction à l'Ancien Testament (red. T. Römer J.-D. Macchi - C. Nihan) (Genève: Labor et Fides 2004) 277-301.

Nissinen, M., Homoeroticism in the Biblical World. A Historical Perspective (Minneapolis, MN: Fortress 1998).

Nissinen, M., „Die Liebe von David und Jonatan als Frage der modernen Exegese”, Biblica 80/2 (1999) 250-263.

Olyan, S.M., „And with a Male You Shall Not Lie the Lying Down of a Women”, Journal of the History of Sexuality 5 (1994) 179-206.

Olyan, S.M., „Surpassing the Love of Women: Another Look at 2 Samuel 1:26 and the Relationship of David and Jonathan", Authorizing Marriage? Canon, Tradition, and Critique in the Blessing of Same-Sex Unions (red. M.D. Jordan) (Princeton, NJ - Oxford: Princeton University Press 2006) 7-16.

Orly, K., „David and Jonathan. A Case of Unconditional Love?”, Journal for the Study of the Old Testament 37/1 (2012) 3-23.

Parpola, S. - Watanabe, K. (red.), Neo-Assyrian Treaties and Loyalty Oaths (State Archives of Assyria 3; Helsinki: Helsinki University Press 1988).

Peleg, Y., „Love at First Sight? David, Jonathan, and the Biblical Politics of Gender”, Journal for the Study of the Old Testament 30 (2005) 171-189.

Petersen, W.L., „On the Study of “Homosexuality” in Patristic Sources”, Patristic and Text-Critical Studies. The Collected Essays of William L. Petersen (red. J. Krans - J. Verheyden) (Leiden: Brill 2012) 110-116.

Pritchard, J.B., Ancient Near Eastern Texts Relating to the Old Testament (Princeton, NJ: Princeton University Press 1969) (= ANET).

Rowe, J., „Is Jonathan Really David's “Wife”? Response to Yaron Peleg”, Journal for the Study of the Old Testament 34 (2009) 183-193.

Rowe, J., Sons of Lovers. An Interpretation of David and Jonathan's Friendship (New York: Bloomsbury 2012).

Römer, T., „Homosexualität in der Hebräischen Bibel? Einige Überlegungen zu Leviticus 18 und 20, Genesis 19 und der David-Jonathan-Erzählung", Was ist der Mensch, dass du seiner gedenkst? (Psalm 8,5). Aspekte einer theologischen Anthropologie. Festschrift für Bernd Janowski Janowski zum 65. Geburtstag (red. M. Bauks - K. Liess - P. Riede) (Neukirchen-Vluyn: Neukirchener 2008) 435-454. 


\section{DARIUSZ DZIADOSZ}

Römer, T. - Bonjour, L., L'homosexualité dans le Proche-Orient ancien et la Bible (Essais Bibliques 37; Genève: Labor et Fides 2005).

Sakenfeld, K., „Love”, Anchor Bible Dictionary (red. D.N. Freedman) (New York: Doubleday 1992) IV, 375-381.

Sakenfeld, K., „Loyalty and Love. The Language of Human Interconnection in the Hebrew Bible", Backgrounds for the Bible (red. D.N. Freedman - M.P. O'Connor) (Winona Lake, IN: Eisenbrauns 1987) 215-230.

Sasson, J., „Gilgamesh Epic”, Anchor Bible Dictionary (red. D. Freedman) (New York: Doubleday 1992) II, 1024-1027.

Sasson, J., „Some Literary Motifs in the Composition of the Gilgamesh Epic”, Studies in Philology 69/3 (1972) 259-279.

Satlow, M., „They Abused Him Like a Woman: Homoeroticism, Gender Blurring, and the Rabbis in Late Antiquity", Journal of the History of Sexuality 5 (1994) 1-25.

Schroer, S. - Staubli, T., „Saul, David, and Jonathan. The Story of a Triangle? A Contribution to the Issue of Homosexuality in the First Testament", Samuel and Kings (red. A. Brenner) (Feminist Companion to the Bible 7; Sheffield: Sheffield Academic Press 2000) 22-36.

Slawik, I. - Slawik, J., „Homoseksualizm problemem Kościoła?”, Rocznik Teologiczny 52/1-2 (2010) 9-69.

Smith, H.P., A Critical and Exegetical Commentary on the Books of Samuel (The International Critical Commentary; Edinburgh: Clark 1992).

Smith, M., "Ancient Bisexuality and the Interpretation of Romans 1:16-27”, Journal of the American Academy of Religion 64/2 (1996) 223-256.

Stansell, G., „David and His Friends: Social - Scientific Perspectives on the David - Jonathan Friendship", Biblical Theology Bulletin 41/3 (2011) 115-131.

Stoebe, H., Das erste Buch Samuelis (Kommentar zum AltenTestament 8/1; Gütersloh: Mohn 1993).

Stoebe, H., Das zweite Buch Samuelis (Kommentar zum AltenTestament 8/2; Gütersloh: Mohn 1994).

Stone, K. (red.), Queer Commentary and the Hebrew Bible (Journal for the Study of the Old Testament Supplement Series 334; Sheffield: Sheffield Academic Press 2001).

Tamagne, F., „Naissance du troisième sexe”, L'histoire 221 (1998) 48-55.

Thompson, J., „The Significance of the Verb Love in the David - Jonathan Narratives in 1 Samuel”, Vetus Testamentum 24 (1974) 334-338.

Tsumura, D., The First Book of Samuel (The New International Commentary on the Old Testament; Grand Rapids, MI: Eerdmans 2006).

Weizer, J., Vom anderen Ufer. Schwule fordern Heimat in der Kirche (Düsseldorf: Patmos 1995).

Wold, D.J., Out of Order. Homosexuality in the Bible and the Ancient Near East (Grand Rapids, MI: Baker 1998).

Wozniak, J., „Drei verschiedene literarische Beschreibungen des Bundes zwischen Jonathan und David”, Biblische Zeitschrift 27 (1983) 213-218.

Zehnder, M., „Exegetische Beobachtungen zu den David - Jonathan - Geschichten”, Biblica 79 (1998) 153-179.

Zehnder, M., „Observations on the Relationship between David and Jonathan, and the Debate on Homosexuality", Westminster Theological Journal 69/1 (2007) 127-174. 